\title{
Geology and stratigraphy of Istanbul region
}

\author{
Nalan LOM \\ Semih Can ÜLGEN \\ Mehmet SAKINC \\ A. M. Celâl ȘENGÖR \\ ITÜ Avrasya Yerbilimleri Enstitüsü, \\ Ayazağa, 34469 İstanbul (Turkey) \\ nalanlom@gmail.com
}

Published on 24 June 2016

This paper is respectfully dedicated to Professor Cazibe (Aruç) Sayar, ITÜ, who did the first detailed geology of the Küçükçekmece area, on the occasion of her retirement from active teaching.

urn:Isid:zoobank.org:pub:7EAA1F61-30B2-4905-A1D9-016E42E01372

Lom N., Ülgen S. C., Sakınç M. \& Şengör A. M. C. 2016. - Geology and stratigraphy of Istanbul region, in Sen S. (ed.), Late Miocene mammal locality of Küçükçekmece, European Turkey. Geodiversitas 38 (2): 175-195. http://dx.doi. org/10.5252/g2016n2a3

\begin{abstract}
The Istanbul region is a part of a bigger continental fragment called the Rhodope-Pontide Fragment. Within this continental fragment, the Istanbul Zone consists, at the base, of a Neoproterozoic middle to high-grade crystalline rocks with relicts of volcanic arc and continental crust, which are not observed in Istanbul itself, but farther east near Zonguldak. This basement is overlain by a continuous, well-developed sedimentary sequence extending from the Lower Ordovician to the Lower Carboniferous. The Carboniferous flysch marks the progress of a shortening event. This event led to the folding and faulting of the Palaeozoic sequence which was intruded by an uppermost Permian granitoid and unconformably overlain by the Upper Permian to Lower Triassic red sandstones and conglomerates. The Triassic series is better formed east of Istanbul showing a typical transgressive development. The Jurassic sequence is absent, most likely as a result of the closure of the Palaeo-Tethys and the resultant generation of the Cimmerides. There is a small outcrop of Lower Cretaceous shallow marine sedimentary rocks and a much more widespread Upper Cretaceous-Lower Eocene clastic, carbonate and andesitic volcanic rocks unconformably covering the Palaeozoic, Triassic and Lower Cretaceous rocks. The pre-Bartonian closure of the Intra-Pontide suture along the Istanbul Zone as a consequence of its collision with the Sakarya Continent created another episode of shortening in this area, an event that was part of the Alpide evolution. The Intra-Pontide suture is the boundary between the Istanbul and Sakarya magmatic arcs in northwestern Turkey. During the Cainozoic, the first post-orogenic structures are Lutetian-Bartonian nummulitic limestones, which themselves are covered by a Paratethyan sequence of Miocene limestones and sandstones of mainly the Vallesian Stage, which include the Küçükçekmece vertebrate bearing horizon. The Pliocene is entirely fluviatile terrestrial clastics. The Pleistocene was deposited on an erosion surface which later became warped and into which the originally fluvial valley of the Bosphorus was entrenched. This valley was invaded by the Sea during the Holocene and caused the refilling of the Black Sea.
\end{abstract}

KEY WORDS

Istanbul,

Küçükçekmece, geological context,

Paratethys,

stratigraphy. 


\begin{abstract}
RÉSUMÉ
Géologie et stratigraphie de la région d'Istanbul.

La région d'Istanbul fait partie d'un fragment continental connu sous le nom de Rhodope-Pontides. Dans cet ensemble, la zone d'Istanbul comprend, à la base, un socle cristallin néoprotérozoïque contenant des reliques de croûte océanique, d'arcs volcaniques et de croûte continentale, qui affleurent seulement à l'est d'Istanbul, près de Zonguldak. Ce socle est recouvert par une séquence sédimentaire continue, bien développée de l'Ordovicien inférieur au Carbonifère inférieur. Le flysch carbonifère reflète une tectonique compressive qui a affecté toute la séquence paléozoïque. Celle-ci a été recoupée par l'intrusion de granitoïdes permiens, puis recouverte en discordance par les grès rouges et les conglomérats du Permien supérieur-Trias inférieur. Le Trias est présent à l'est d'Istanbul et montre un caractère transgressif. Le Jurassique est absent, probablement à cause de la fermeture de la PaléoTéthys et la formation des Cimmerides qui en résultent. Seuls le Crétacé supérieur et le Paléocène sont bien développés dans la région d'Istanbul, avec un cortège de sédiments clastiques, de carbonates et de roches volcaniques andésitiques qui recouvre en discordance les terrains antérieurs. La fermeture de la suture intra-Pontides le long de la zone d'Istanbul lors de sa collision avec le Continent de Sakarya a provoqué un autre épisode compressif important durant l'évolution Alpide de la région. Les premières formations post-orogéniques sont des calcaires nummulitiques du Lutétien-Bartonien, suivis par une séquence de calcaires et de sables miocènes du domaine de la Paratéthys, principalement d'âge Vallésien, qui incluent le gisement de vertébrés de Küçükçekmece étudié ici. Le Pliocène est représenté par des dépôts fluviatiles clastiques. Le Pléistocène a été déposé sur une surface d'érosion, déformée ultérieurement et dans laquelle s'est creusée la vallée fluviale qui est à l'origine du Bosphore. Cette vallée fut ennoyée par la mer au cours de l'Holocène, ce qui a conduit au remplissage de la Mer Noire.
\end{abstract}

\section{INTRODUCTION}

Istanbul is the most populous city in Turkey, and the country's economic, cultural, and historical centre. Its unique geography, convenient climate and natural resources have drawn attention for ages. The history of Istanbul goes back to $400 \mathrm{ka}$. The first traces of human culture were discovered in the excavations carried out in the Yarımburgaz Cave on the banks of the Taş Deresi emptying into the Küçükçekmece Lagoon in the north. It is thought that Palaeolithic, Neolithic and Chalcolitic people lived in a number of localities in Istanbul. The City has witnessed the rise and fall of the world's most famous empires throughout its history. Owing to its location within these empires, commonly as their capital, Istanbul has undergone various name changes. Istanbul, once known as Constantinople and Byzantium before that (plus 46 other names), is a transcontinental city in Eurasia. The Bosphorus Strait divides the city into European and Asian parts and connects the Sea of Marmara with the Black Sea.

The City was mapped for the first time, albeit very crudely, by the French entomologist Guillaume-Antoine Olivier (1756-1814) who had been sent to Istanbul by the French National Convention. This map was published in 1801, in the atlas volume of "Voyage dans l'Empire Ottoman, l'Égypte et la Perse". Later on, in 1837 the second geological map published by French palaeontologist Philippe Edouard Poulletier de Verneuil (1805-1873) in a short article entitled "Notice géologique sur les environs de Constantinople". The first modern coloured geological map of Istanbul belongs to the Russian Prince Piotr Alexandrovich de Tchihatcheff (1808-
1890). He describes the rocks from the vicinity of the Bosphorus in his two great works, "Asie Mineure" (1856-1869) and "Le Bosphore et Constantinople avec Perspectives des Pays Limitrophes" (1864). Ferdinand Roemer (1818-1891), a German geologist, worked on the Devonian sediments, and created a new solitary coral species, Pleurodyctium constantinapolitanum. An Austrian jurist and medical doctor, Karl Eduard Hammerschmidt (1799-1874) also known as "the Hungarian" Abdullah Bey after he fled his country via Hungary and sought refuge in Ottoman Empire, was also interested in Devonian rocks, he collected fossils and sent them to de Verneuil. The fossil collections from Istanbul led to some discussions among the researchers about the existence of Cretaceous rocks in this area. It was not ascertained until 1930, when a geologist Ernest Chaput (1880-1943) and a biologist Raymond Hovasse (1895-1989) discovered fossiliferous Cretaceous layers in the northern part of Istanbul (Chaput \& Hovasse 1930).

The classical publications about the Triassic rocks around Istanbul started with the Austrian geologist Franz Toula (1845-1920) in 1896, and he is the first researcher who recognized the Triassic rocks in this region. Later on the German geologist Wilhelm Endriss (1910) and the Austrian geologist Gustav von Arthaber (1864-1943) worked on this Triassic sequence. Von Arthaber (1914) extended the fossil collection and showed that the sequence starts from the lowermost Triassic and reaches up to the Carnian. Walther Penck (1888-1923), a geologist who was invited to Turkey during the World War I, established a geological institute and mainly worked on the geology around the Bosphorous. He published his work, Grundzüge der Geologie des Bosporus in 1919 in which a Palaeozoic magmatism was first mentioned. 


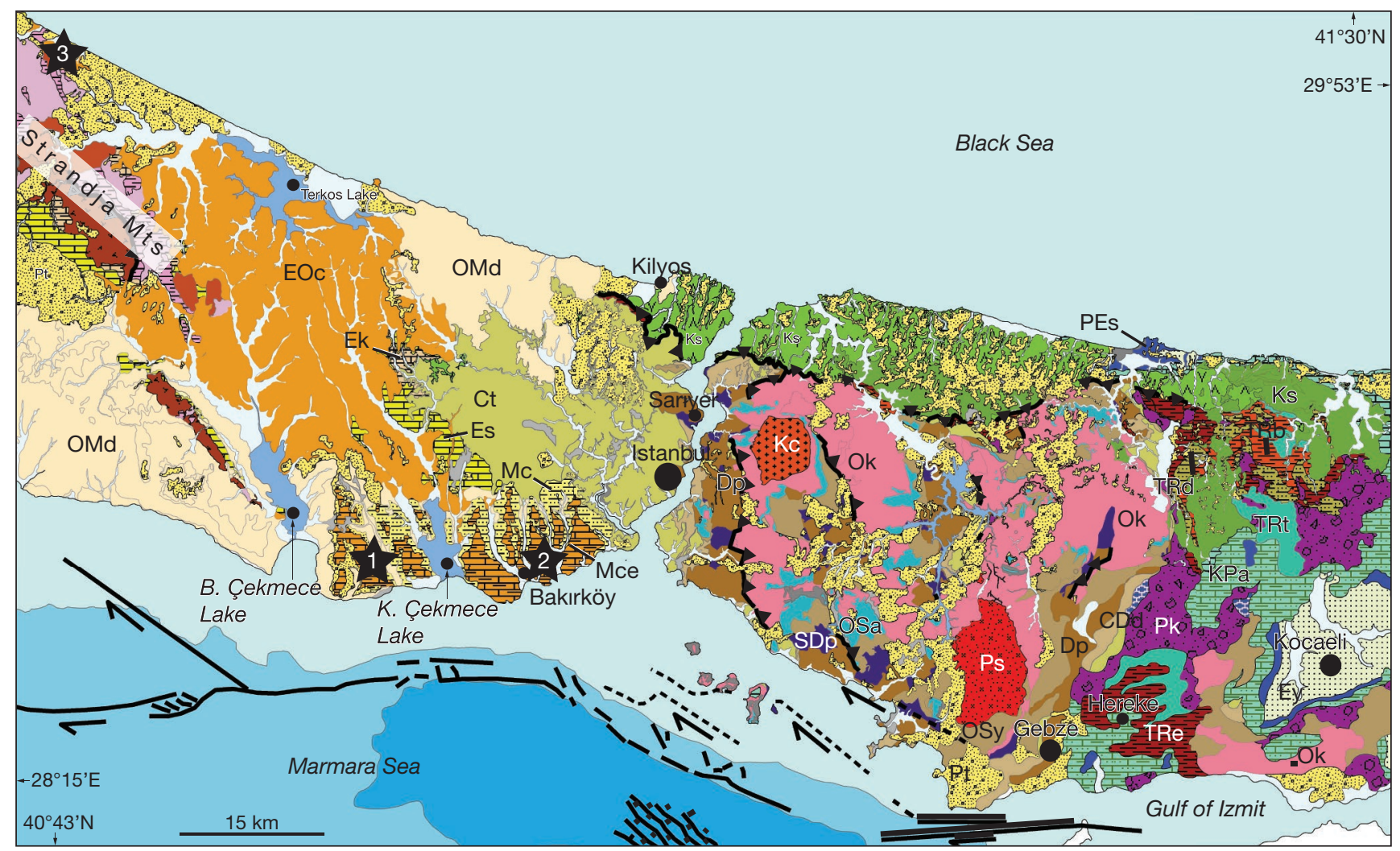

\begin{tabular}{|c|c|}
\hline \multicolumn{2}{|c|}{ Sedimentary Rocks and Volcanics } \\
\hline HOLOCENE & $\square$ Alluvium \\
\hline PLIOCENE & Pt: Thrace Stage-Belgrad Gravels \\
\hline MIOCENE & 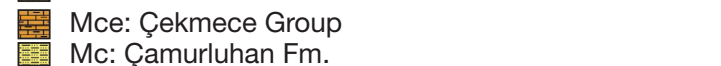 \\
\hline OLIGOCENE & $\begin{array}{l}\square \text { OMd: Danişmen Fm. } \\
\square \text { EOc: PInarhisar Fm.-Karaburun Fm.-Ceylan Fm. }\end{array}$ \\
\hline EOCENE & $\begin{array}{l}\text { Es: Soğucak Fm. } \\
\text { Ek: Koyunbaba Fm. } \\
\text { Ey: Yunuslubayır Fm. }\end{array}$ \\
\hline PALAEOCENE & $\begin{array}{l}\text { PEs: Şile Fm. } \\
\text { KPa: Hereke Conglomerate-Kutluca Ls.-Akveren Fm. }\end{array}$ \\
\hline $\begin{array}{r}\text { UPPER } \\
\text { CRETACEOUS }\end{array}$ & $\begin{array}{l}\text { Ks: Sarıyer Group-Andesitic basalt } \\
\text { Ks: Sarıyer Group-debris flow }\end{array}$ \\
\hline TRIASSIC & $\begin{array}{l}\text { TRt: Tepecik Fm. } \\
\text { TRb: Ballıkaya Fm. } \\
\text { TRd: Demirciler Fm. } \\
\text { TRe: Erikli Fm. }\end{array}$ \\
\hline PERMO- & Pk: Kapaklı Fm-Basalt-spilit \\
\hline TRIASSIC & Pk: Kapaklı Fm. \\
\hline LOWER CARBON. & $\square$ Ct: Trakya Fm. \\
\hline DEVONIAN & $\begin{array}{l}\square \text { CDd: Denizliköyü Fm. } \\
\text { Dp: Pendik Fm. }\end{array}$ \\
\hline SILURIAN & $\begin{array}{l}\square \text { SDp: Pelitli Fm. } \\
\square \text { OSy: Yayalar Fm. }\end{array}$ \\
\hline ORDOVICIAN & $\begin{array}{l}\square \text { OSa: Aydos Fm. } \\
\text { Ok: Kocatöngel Fm.- Kurtköy Fm. }\end{array}$ \\
\hline
\end{tabular}
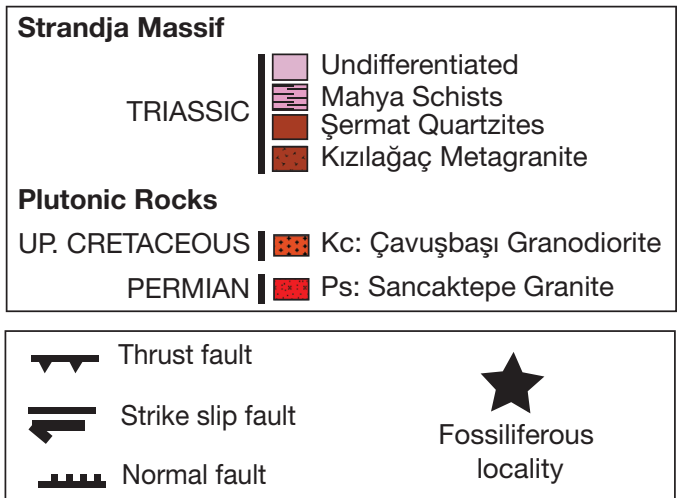

FIG. 1. - Geological map of Istanbul and its surroundings. Modified according to Türkecan \& Yurtsever (2002) and Özgül (2011).

An important contribution to the stratigraphy of Istanbul and its correlation with the European equivalents came from a German geologist, Werner Paeckelmann (1890-1952). He mapped the area between Çengelköy-Bostancı and Üsküdar (Paeckelmann 1925; 1938). Until the 1950's the geological studies in Istanbul were carried out by Europeans. By the second half of the $20^{\text {th }}$ century Turkish geologists begin to show up in greater frequency in the geological arena. Şakir Abdüsselâmoğlu, a geologist from İTÜ (Istanbul Technical University), published a paper in 1963 about the Devonian 
and Carboniferous rocks and placed them correctly in the geological time scale. Cazibe (Arıç) Sayar, a geologist also from the İTÜ, worked on the quartzites and the Ordovician fossils she found, showing the age of this series (Sayar 1964). This discovery made the correlation with Europe, Northern Caucasus and the Uralides much easier.

The Cainozoic rock assemblages have a much simpler structure than the older units. At the beginning of the 19th century these rocks were already recognized by de Verneuil. The first publication addressing particularly the geology of western Istanbul belongs to de Verneuil in his 1837 paper which is already mentioned earlier. De Verneuil made the first geological observations on the Tertiary rocks. In his map he divided the area into three. The area mapped as "Terrain tertiaire" is the equivalent of the Cainozoic rocks. A more detailed study was carried out by the French-Austrian huguenot geologist Ami Boué (1794-1881) in 1840. Boué published a detailed map of the Rumelia, including also the western part of Istanbul, and he described the Oligocene clastics in the vicinity of Tekirdağ as "Molasse" and pointed out that they extend to Küçükçekmece with calcareous marl containing bivalve fossils, such as Mactra and Venus. He concluded correctly that the Cainozoic rocks from western Istanbul correlate with the youngest members of Cainozoic in Hungary and Austria. However, he didn't suppose a direct sea connection between the western Istanbul and, Hungary and Austria. The subsequent studies by the German geologist Christian Gottlieb Ferdinand Ritter von Hochstetter (1829-1884) and the French and Austrian geologists showed that these sediments were accumulated in an inland sea that stretched from the region north of the Alps over Central Europe to the Aral Sea in Central Asia (the Sarmatian Sea of Suess 1866).

\section{TERminology}

The term early refers to time, whereas Lower refers to rock. Time terms cannot be formalised and that is why written in small case letters (i.e. early, medial, late) contrary to the recommendations of the International Stratigraphic Guide, second edition (Salvador 1994). By contrast, rock terms can be formalised (because they refer to a measurable volume of rock) and are written in capital letters (i.e. Lower, Middle, Upper). The problem with the formalisation of time is that no method is capable of giving us a time horizon that can be tied to rocks globally. For example, not everywhere a "late Triassic" can signify the same time slice as applied to the duration of the formation of a certain rock volume, whereas a rock volume, if it contains the necessary index fossils, can be unequivocally fixed as being Upper Triassic.

\section{PALAEOZOIC ROCKS}

The Istanbul Palaeozoic sequence is an exotic body with respect to the surrounding rocks in the region. The Istanbul Zone consists of a middle to high-grade crystalline latest Proterozoic, possibly Pan-African, basement (Arpat 1978;
Ustaömer 1999; Chen et al. 2002), overlain by a continuous, well-developed very low grade metamorphosed sedimentary sequence extending from the Lower Ordovician to the Lower Carboniferous. This Palaeozoic sequence starts with a regressive series from Lower Ordovician to Lower-Middle Ordovician and then continues transgressively until the Lower Carboniferous. Because the Rb-Sr mica ages of Ediacaran (548-545 Ma) are preserved, Chen et al. (2002) suggest that there has been no reheating during the three orogenic events that affected the region; Hercynian, Cimmeride and Alpide orogenies that are enough to reset the micas.

The latest published studies on the Palaeozoic stratigraphy of Istanbul are Özgül (2011 and 2012). In these publications he describes nine formations: Kocatöngel Formation (Lower Ordovician), Kurtköy Formation (Lower Ordovician), Kınalıada Formation (Middle-Upper Ordovician), Aydos Formation (Middle-Upper Ordovician), Yayalar Formation (Upper Ordovician-Lower Silurian), Pelitli Formation (Upper Silurian-Lower Devonian), Pendik Formation (Middle-Upper Devonian), Denizli Köyü Formation (Middle Devonian-Lower Carboniferous) and Trakya Formation (Lower Carboniferous) (Fig. 1).

The lowermost unit is the Kocatöngel Formation consisting of clastics that are considered as covering a basement that is not exposed within the province limits of Istanbul. The inference is made on the basis of outcrops farther east. The Kocatöngel Formation was originally described in Sakarya, east of Istanbul, by Yazman \& Çokuğraş (1983). Gedik et al. (2002) are the first to mention these grey-green laminated shale-siltstones in Istanbul. Özgül (2012) thought that this laminated stack presents a varved sequence. However, Gedik et al. (2002) suggested that they indicate a deep marine environment. Our own later observations in the company of Professor Daniel Bernoulli revealed that this sediment pile consists of a turbidite, possibly marine or lacustrine. The whole Bouma sequence is not observable but the graded bedding, parallel lamination and convolute lamination are observable in the east of Mahmut Şevket Paşa village. The Kocatöngel Formation does not contain any fossils in Istanbul. The succeeding Kurtköy Formation consists of purple-green arkosic shale-siltstone-sandstone intercalations in the lower levels and continues with conglomerates in its upper levels. Paeckelmann (1938) mentioned this formation in his study as "Hauptkonglomerate (basal conglomerates) und ArkoseHorizont". The name Kurtköy was given later by Haas (1968). Deposition of these arkosic sediments also began with turbidites but rapidly became shallow water and then terrestrial fanglomeratic clastics. Gedik et al. (2002) refer the lower part of the sequence to a deltaic environment. This deltaic sequence may have been deposited in a tectonically active environment (rift?) and is herein interpreted to have been laid down under dry and/or cold climate conditions. Görür et al. (1997) suggested that the climatic conditions are related to the Ordovician Gondwanian (or Saharan) Glaciation. Ages of both the Kocatöngel and the Kurtköy Formations are determined by means of stratigraphic correlation. Dean et al. (2000) give a Tremadocian (earliest Ordovician) age for 


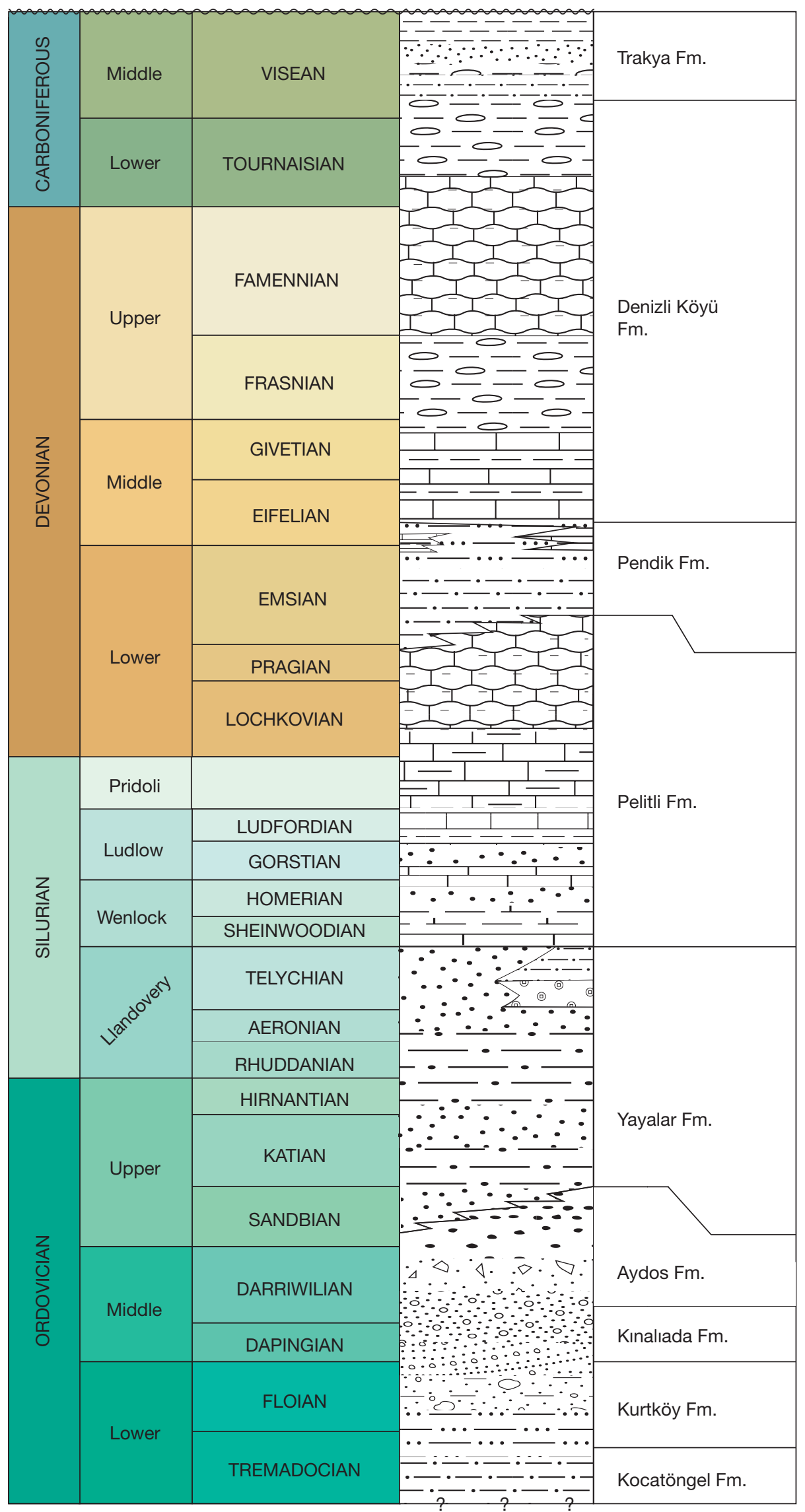

FIG. 2. - Generalized stratigraphic section of the Palaeozoic sequence. Modified from Özgül (2012). 
the equivalents of the lower levels of the Kurtköy Formation around Karadere to the east of Istanbul, near Zonguldak by the help of acritarchs. Based on these data, the age of the Kurtköy and Kocatöngel Formations were determined as Lower Ordovician (Özgül 2012) (Fig. 2).

The continental deposits of the Kurtköy Formation are followed by the feldsphatic sandstones and feldsphatic quartz arenites of the Kinalıada Formation. The Kinalıada Formation is usually considered as part of the Aydos Formation by Kaya (1978) and Önalan (1981). It was separated as an independent formation by Özgül $(2011,2012)$. These tidal deposits are probably in lateral transition with the Kurtköy and the Aydos formations. The Aydos Formation was first described by Paeckelmann (1938) and later elaborated upon by Kaya (1978) and designated as a formation by Önalan (1981). The Aydos Formation is represented by quartz arenites, quartz conglomerates and shales that are considered to be deposited on a beach and lagoon. The Aydos Formation probably represents the end of the regression and the beginning of a new transgression in the basin. Haas (1968) and Önalan (1981) reported trace fossils and proposed an age of Upper Ordovician. Özgül (2012) considered Upper Ordovician-Lower Silurian age because it shows gradational contacts with the overlying Yayalar Formation, which is broadly of the same age. According to the overlying Yayalar Formation the age of the Aydos Formation is considered as Middle-Upper Ordovician. Ustaömer et al. (2011) did U-Pb dating on detrital zircons of the Aydos Formation for provenance analysis and concluded that the continental Istanbul Fragment was a part of NW Gondwana-Land because of their proposed correlations with the Amazonian Craton, which we consider unlikely because its seems well-nigh impossible to bring the Istanbul Fragment from their proposed location to its present position by the subsequent tectonic events. But the Gondwanian origin, possibly from some other Gondwanian margin, is almost certain due to the Pan-African basement of the Istanbul Zone, the stratigraphic resemblance with some Central and Southern European units for the Ordovician time (Carnic Alps, Bohemian Massif, mostly Saxo-Thuringia Unit), faunal similarities with the Bohemian Massif in the medial Ordovician (Sayar 1964), an inferred 30-40 S palaeolatitude for the Istanbul Zone in Upper Ordovician (Sayar \& Cocks 2013), cold climate environment requirement for the arkoses and proximity of the Saharan glaciation.

The Aydos Formation is followed by the micaceous feldspathic sandstones of the Yayalar Formation. This formation has been studied many times: first Paeckelmann (1938) described it as the "Halysites-Grauwacken-Horizont"; Haas (1968) designated it as the Yayalar Formation. However Tüysüz et al. (2004) described it under the name Gözdağ Formation in the stratigraphic commission book citing Önalan's nomenclature (1981). We think Haas has priority and his designation must be preserved. In view of its contained fossils (brachiopods, conularia, graptolites, conodonts) (Sayar 1964, 1979, 1984; Haas 1968; Önalan 1981; Göncüoğlu et al. 2006) the age of Yayalar Formation is considered Llandoverian (Lower Silurian). The sudden influx of micas here might be indicative of a
post-Pan African event, the nature of which remains unclear. It may have been related to topography created by strike-slip faulting, because no evidence of collision is seen anywhere in the sedimentary sequence, contrary to the interpretation by Okay \& Nikishin (2015).

After the pro-delta facies sediments of the Yayalar Formation, transgression in the basin continued with shallow marine limestones of the Pelitli Formation. These limestones were studied by Penck (1919) first and afterwards have been called by many different names. They are rich in fossils (corals, crinoids, brachiopods, stromatoporoids) and different studies agree in assigning them to an interval going from the Lower Silurian to the Lower Devonian (Haas 1968; Abdüsselamoğlu 1977; Saydam 2005; Göncüoğlu et al. 2006; Özgül et al. 2009). The Pelitli limestones represent reef margin and open shelf environments under warm climatic conditions. The micaceous shales of the Pendik Formation conformably overlie the limestones of Pelitli and indicate increasing clastic sediment input into the basin. These shales were first defined by Paeckelmann (1938) as the "Pendik Schichten", but later called the Kartal Formation by different researchers (Önalan 1981; Tüysüz et al. 2004). Especially the lower part of the Pendik Formation is rich in macro fossils like tabulate corals (Pleurodictyum sp.), brachiopods, trilobites etc. Studies on macrofossils (Paeckelmann 1938; Babin 1973; Carls 1973; Gandl 1973; Kaya 1973; Önalan 1981; Dojen et al. 2004; Sayar \& Cocks 2013) suggest a Lower-Middle Devonian age. The conformably following Denizli Köyü Formation consists of limestones, shales, nodular limestones and radiolarian cherts with phosphate nodules. This formation represents an oxygen-rich, open and deepening shelf environment without significant clastic input. Different palaeontological data give an age of late Emsian to Tournasian for this unit (Abdüsselamoğlu 1963; Haas 1968; Noble et al. 2008). The top part of the Denizli Köyü consists entirely of phosphatic cherts with no limestones. We interpret this as indicative of a subsidence below the CCD. Over these deep marine sediments, thick turbiditic flysch deposits with limestone intercalations were emplaced, namely those of the Trakya Formation. Penck (1919) is the first person who described the unit. He thought that this was a continental sediment. Paeckelmann (1938) considered these rocks as marine sediments and correlated them with the Kulm series in Germany. Fossils gathered from the shales and the limestone give a late Tournasian to late Visean age (Abdüsselamoğlu 1963; Kaya \& Mamet 1971; Mamet 1973; Göncüoğlu et al. 2006). Deformation and unconformity between this flysch with the overlying units have made the researchers think that flysch deposition was related to the Hercynian Orogeny in Europe (Paeckelmann 1938; Ketin 1959; Görür et al. 1997). Okay et al. (2011) suggested a Late Devonian to Early Carboniferous magmatic and metamorphic province with overprinted Neoproterozoic basement which they interpreted as Armorican Massif. However, the position of Istanbul Fragment during this collision is still controversial today.

The main structural components in the Istanbul Palaeozoic sequence are N-S trending thrusts. Vergence of these thrusts 


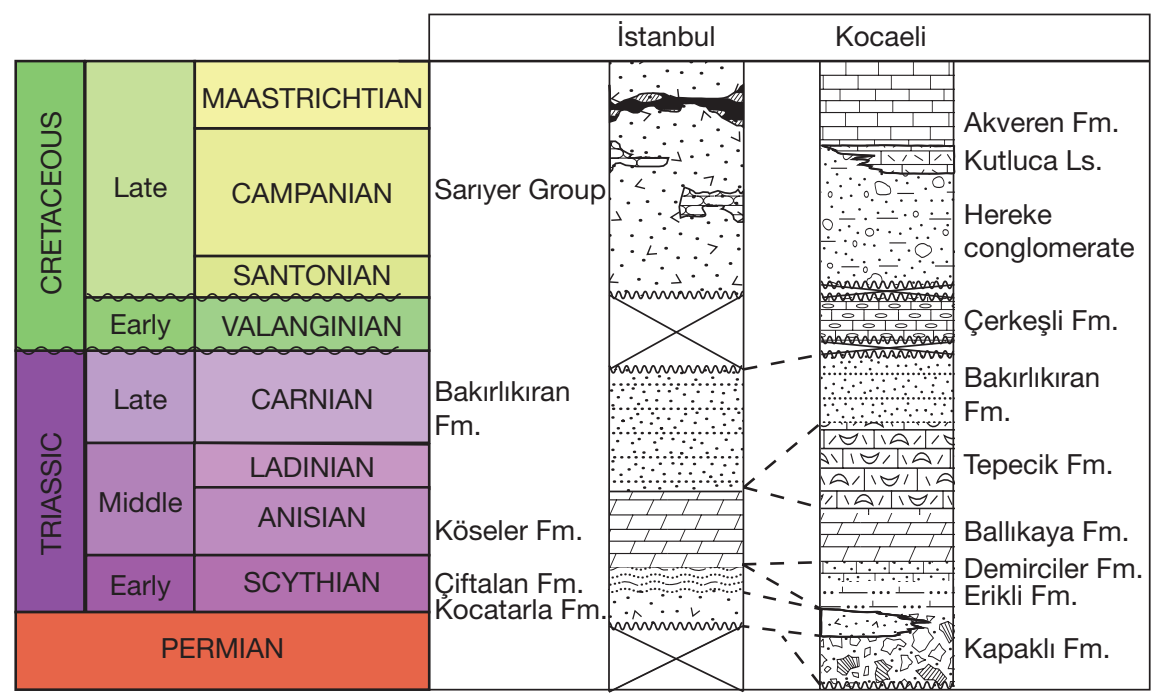

FIG. 3. - Generalized stratigraphic section of the Mesozoic sequence in Istanbul and in Kocaeli.

are considered to the west and the entire sedimentary sequence to have been deformed on a décollement surface (Şengör \& Özgül 2011). Under this deformation, thick and competent arkoses are folded with long wavelengths, cut by big thrusts, and show spaced cleavage. Devonian shales are folded with shorter wavelengths, and they show evidence of plastic deformation such as similar folds and in some regions they show severe folding probably related to local high strain. In many places, the presence of kink folds indicates more brittle behaviour. It seems that the Palaeozoic sequence is squeezed between the Ordovician arkoses and Carboniferous flysch. Carboniferous flysch is characterized by parallel folding and flexural slip along bedding planes, which most likely indicate a basal décollement. Lack of metamorphism and penetrative structures show that this Palaeozoic sequence was deformed in a marginal fold-and-thrust belt. Whether it was a foreland or a hinterland fold and thrust belt is as yet uncertain. Our suspicion is the latter because of the small-scale of the entire system and the lack of abundant ophiolitic clasts in the flysch sequence that can be related with the ongoing subduction.

\section{MESOZOIC ROCKS}

A shortening event of as yet unknown cause in the early Carboniferous occasioned folding, faulting, and consequently uplift and emergence of the Istanbul area. Permian is represented there by intrusions of granitic bodies. The Sancaktepe Granite $(253.7 \pm 1.75 \mathrm{My})$ has been interpreted as a product of the Hercynian Orogeny, emplaced in a post-collisional tectonics such as the Permian granitic plutons widespread in Europe (Bürküt 1966; Yılmaz 1977; Yılmaz-Şahin et al. 2010). The Permian?- Lower Triassic terrestrial sediments unconformably overlie the Palaeozoic sequence. The Mesozoic sequence shows different characteristics in Istanbul and in the neighbouring city of Kocaeli (ancient Nicomedia). The Triassic sequence in Kocaeli starts with red coloured conglomerate, sandstone and siltstone, collectively called the Kapaklı Formation (Altınlı 1968; Tüysüz et al. 2004), consisting basically of reworked sediments of the Palaeozoic rocks. Toula (1898) classifies these sediments as Rothliegendes, i.e. the "Lower New Red". This formation indicates an arid and warm desert environment, but it does not have any fresh feldspar in it. The Permo-Triassic Kapaklı Formation sedimentary rocks contain basaltic and rhyolitic intercalations along the shores of the Gulf of İzmit, herein interpreted as indicating rift formation in a transtensional environment extending from Central Asia to southern Europe in the Triassic (Natal'in \& Şengör 2005). The Kapaklı Formation passes into the Scythian Erikli Formation which contains clastics and shallow water carbonate lenses (Özgül 2011). This Formation was first described by Yurtsever (1982). The Lower Triassic Demirciler Formation overlies the Erikli Formation. The sandy limestone of the Demirciler Formation (Tüysüz et al. 2004) indicates a transition from a continental to a tidal environment. The overlying Ballikaya Formation (Scythian?-Anisian) contains dolomitic limestones and dolomites, and characterizes a shallow shelf setting (Yurtsever 1982). The succeeding Tepecik Formation (Upper Anisian-Lower Carnian) consists of limestone and flintstone with abundant Ammonite fossils, and it is interpreted as indicating a comparatively deeper environment (Erguvanlı 1947; Altınlı et al. 1970; Yurttaş-Özdemir 1971). The upper part of Tepecik Formation is in the Ammonitico Rosso or Hallstatt Facies. Red, nodular, pelagic limestones commonly, but not necessarily, containing ammonite moulds have been described as the Ammonitico Rosso facies irrespective of age, but originally it is first used in Northern Italy to indicate pelagic limestones which were widespread in the Jurassic Neo-Tethyan Ocean. The uppermost part of the Tepecik Formation is a flysch type sequence of sandstone and shale with Halobia sp. (Nicora 1973; Yurttaş-Özdemir 1973; Gedik 1975; Dağer 1980; Sestini 1988). This formation can be linked to the onset of latest Triassic Cimmeride deformation (Fig. 3). 


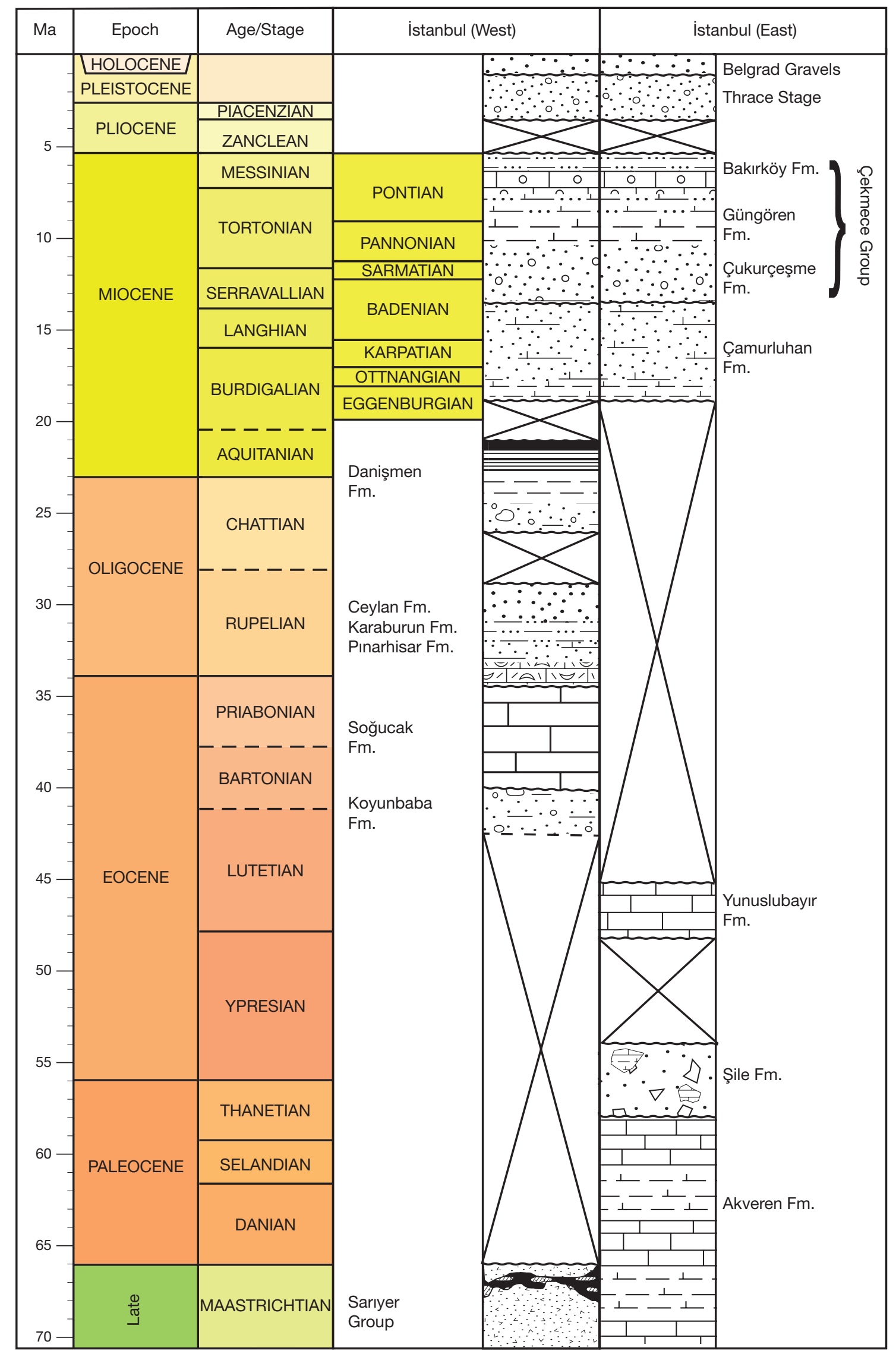

FIG. 4. - Generalized stratigraphic section and correlation of the post-Cretaceous stratigraphic sequence in Istanbul region. 


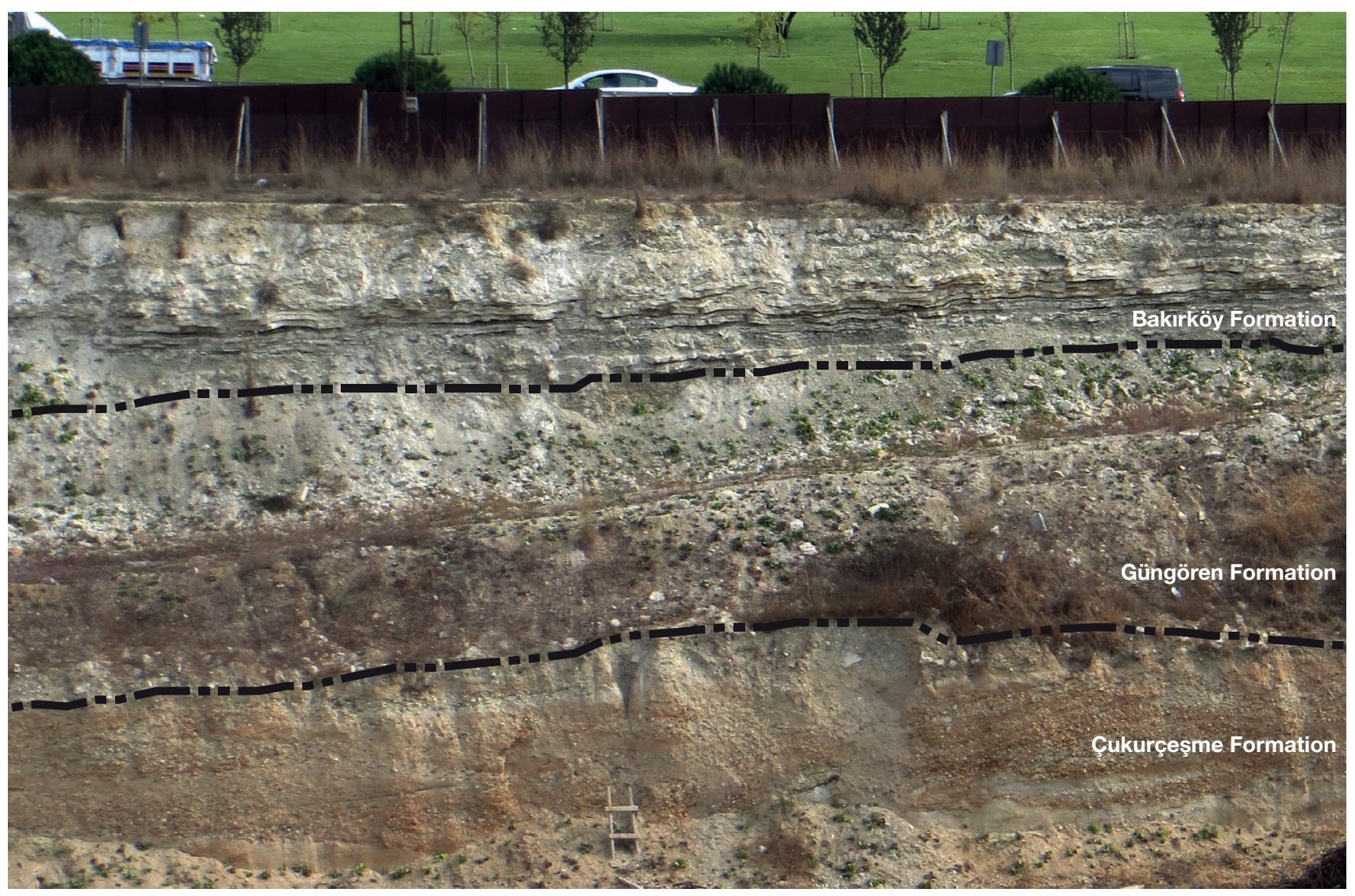

FIG. 5. - Outcrop view of Çekmece Group. East of Büyükçekmece Lake, Beykent Site (view to the NE). Black star number 1 on the map.

In the northwestern part of Istanbul, the Triassic sequence, cropping out within the thrust slices around Kilyos, is composed of four main rock units. Kaya \& Lys (19791980) describe this Triassic sequence as follows: The Scythian (Lower Triassic) Kocatarla Formation is essentially an altered uniform, massive basaltic lava flow with sporadic vacuoles indicating subaerial or shallow water eruptions. It unconformably overlies the Carboniferous rocks. This lava flow can be correlated with the basaltic intercalations of the Kapaklı Formation. The succeeding Çiftalan sandstone consists of whitish, thickly-bedded to massive sublitharenite and quartz-arenite. The sandstones are mainly fine-to medium-grained, and cemented with silica. The contact between the Çiftalan and the Kocatarla formations is not exposed. The Upper Scythian-Anisian Köseler Limestone consists mainly of dolomitized limestone. On the basis of its lithologic and age significance the unit can be correlated with the Ballıkaya Formation of the Kocaeli Triassic sequence. The Tepecik Limestone is absent in Istanbul, but Carnian? rocks, the thin Bakırlıkıran Formation, is observed in both regions. It contains sandstones with various plant fossils. Latest Triassic and Jurassic rocks are absent in this region. The early Cretaceous is also mostly absent, save for one small area, which is reported by Kaya et al. (1987) in Gebze: the Çerkeşli Formation rests unconformably on the Triassic rocks, with limestone-pebble conglomerate derived almost entirely from the Triassic carbonates. The foraminifera in the matrix of the limestone-pebble conglomerate and an ammonite in the shale give an Lower Cretaceous (Valanginian) age for the Çerkeşli Formation. A significant observation here is the presence of an Upper Jurassic coral in the clasts indicating the former presence of an Upper Jurassic cover here.

The almost total absence of Jurassic rocks can be explained by the syn- to post-orogenic emergence and erosion of this area. The Cimmeride deformation was ascribed to the closure of the Palaeo-Tethys ocean following the collision of a Cimmerian continental sliver with the southern margin of Laurasia (Şengör et al. 1980; Şengör \& Yılmaz 1981). This was preceded and partly accompanied by the opening of a new branch of the Tethys, the Neo-Tethys, on the southern side of Istanbul, as a back-arc basin. However, this rifting event cannot be observed within the limits of the province of Istanbul, save for an as yet unsubstantiated claim of a few Liassic dykes along the Sea of Marmara along the Anatolian shores of Istanbul according to the K/Ar ages obtained from whole rocks (Sen et al. 2015).

The Strandja mountains (Pamir \& Baykal 1947; Gocev 1979; Ketin 1982; Gocev 1991; Natal'in et al. 2012) are another recorder of the Cimmeride Orogeny. The basement together with the Lower Mesozoic sedimentary cover was penetratively deformed and imbricated by north-verging 


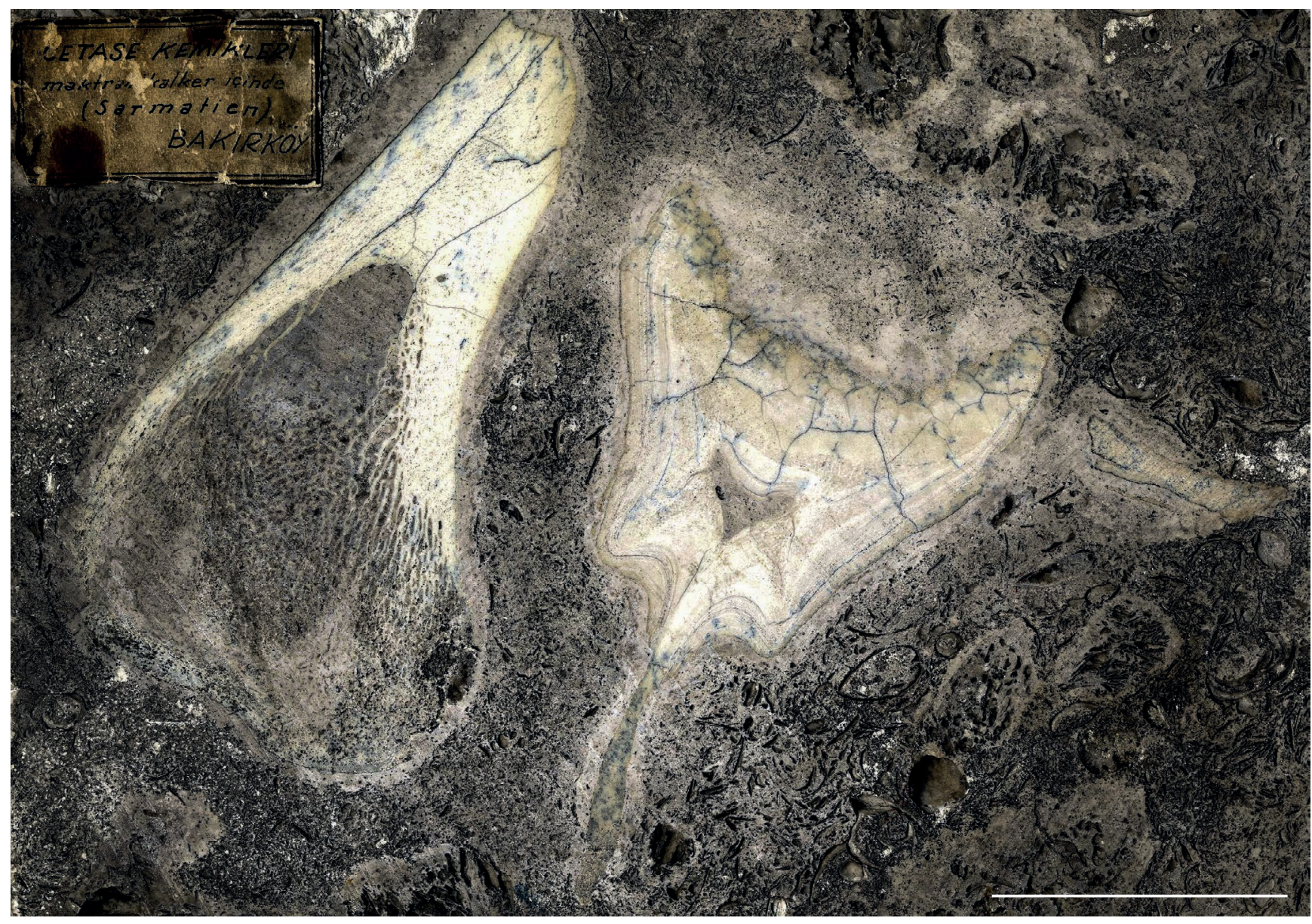

FıG. 6. - Bakırköy Formation: Mactra (Bivalvia) and Cetacea bones, Bakırköy, Istanbul. Black star number 2 on Figure 1. Scale bar: $5 \mathrm{~cm}$.

thrusts probably during the Late Jurassic-Early Cretaceous, accompanied by a regional metamorphism. (Okay et al. 2001). The Strandja Massif, exposed in NW Turkey, consists of greenschist to epidote amphibolite facies metamorphic rocks that are subdivided into a Palaeozoic basement that is intruded by granites and a Triassic-Jurassic sedimentary cover (Sunal et al. 2006). Three different units are distinguished within the Istanbul city, in the Çatalca region. The oldest Lower Permian Kızılağaç Metagranite is dominated by granitic gneisses and preserves nonconformable contacts with the overlying Permo-Triassic Şermat Quartzites (mapped by Çağlayan \& Yurtsever 1998). This rock association, which represents a crystalline basement and shallow-marine stable shelf deposits, is tectonically mixed with a thick pile of schist and rare metasandstones that in places contain tectonic lenses of exotic lithologies such as metacherts, metavolcanics and thinly-bedded alternation of metacherts and marbles indicating pelagic environments. Çağlayan \& Yurtsever (1998) mapped this unit as the Triassic Mahya Schists. The Mahya Schists are interpreted as a Triassic accretionary wedge (Şengör \& Özgül 2011; Natal'in et al. 2012). These three units with different tectonic settings reveal strong tectonic mixing. The Mahya Schists and the Şermat Quartzite show similar tectonic transport of the late stage of the Jurassic-early Cretaceous deformation established in the western part of the Strandja Massif. The late Palaeozoic magmatic activity is studied by Sunal et al. (2006). Their $\mathrm{Pb} / \mathrm{Pb}$ zircon evaporation results of the orthogneisses constituting the Paleozoic basement indicate Carboniferous magmatic activity at 310 to $320 \mathrm{Ma}$, and after an episode of metamorphism and deformation, it was followed by emplacement of the Lower Permian $(257 \pm 6 \mathrm{Ma})$ monzogranites. The geochemical features of this magmatics allow considering them as subduction related (Sunal et al. 2006). Late Palaeozoic (late Carboniferous) subduction-accretion in the Strandja Massif is correlative with synchronous orogeny in the Balkans.

A new transgression started during the late Cretaceous after the Cimmeride deformation in the Istanbul-İzmit region. The Cretaceous units sit on the Palaeozoic and Triassic units with angular unconformity. The Hereke conglomerate (the Hereke Pudding) in Kocaeli developed in a transgressional environment, with high energy mixing of gravels of various sizes, eroded from the underlying Palaeozoic and Triassic sediments and the Permian Granite (Erguvanlı 1949; Altınlı et al. 1970). Its variegated pinkish appearance makes it one of the most popular ornamental stones in Istanbul. These ornamental stones have been frequently used to decorate 


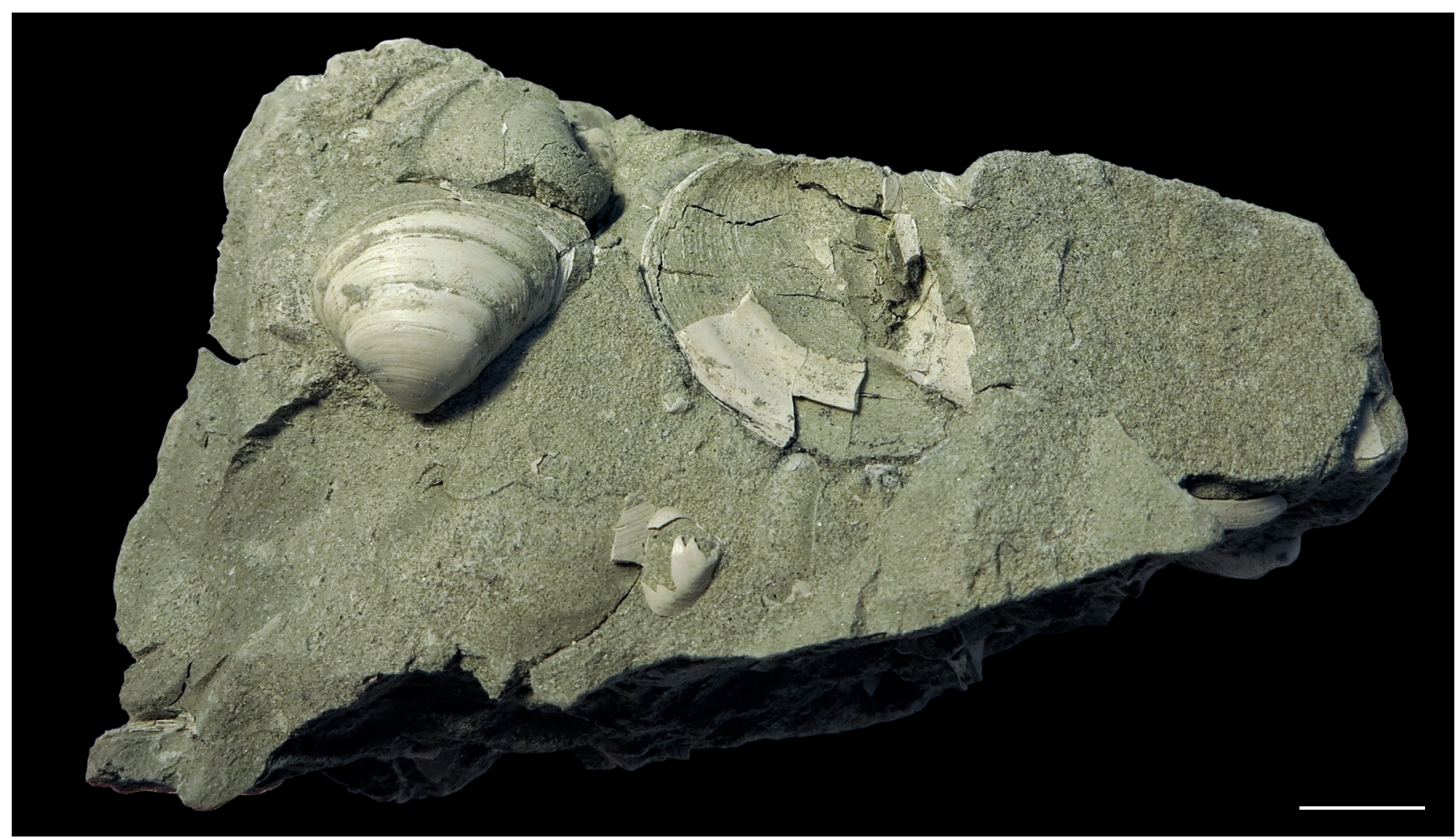

FIG. 7. - Mactra fossils from Haramidere, Bakırköy Formation (Near Küçükçekmece). Black star number 1 on Figure 1. Scaler bar: $10 \mathrm{~cm}$.

floors and columns of the monumental buildings of the City. The succeeding Campanian Kutluca Limestone has a lateral transition with Hereke conglomerate. This onlapping biostrome was simply called a rudist limestone (Gebzestone) by Erguvanlı (1949).

While basal conglomerates were being laid down on the eastern side of Istanbul, the andesitic volcanic rocks of the Sariyer Group covered large areas in the northern part of the region, throughout the Pontides. The Yemişliçay Group farther east (called the Sariyer Group in Istanbul) consists of basaltic and andesitic tuffs, agglomerates, lava flows, volcanogenic sandstones and shales (Ketin \& Gümüş 1963). Gedik et al. (2005a) describe a late Santonian-Campanian fauna of planktonic foraminifera and nannofossils from the volcanogenic series.

The Çavuşbaşı Granodiorite and the andesitic dykes intruded into the Palaeozoic sequence have also been formed in this period. The Upper Cretaceous $(67.91 \pm 0.63 \mathrm{Ma}$ and $67.59 \pm 0.5 \mathrm{Ma}$ ) Çavuşbaşı Granodiorite has a fine- to medium-grained granodioritic and tonalitic composition, with a generally metaluminous, middle-K, calk-alkalic I-type character (Yilmaz-Şahin et al. 2012). The U-Pb zircon ages of the calc-alkaline andesitic to dacitic dykes yield ages ranging from $72.49 \pm 0.79$ to $65.44 \pm 0.93 \mathrm{Ma}$ (Upper Cretaceous) (Aysal et al. 2015). The arc magmatism is ascribed to the north-dipping subduction of the Neo-Tethyan Ocean along the İzmir-Ankara-Erzincan suture (Şengör \& Yılmaz 1981; Keskin \& Tüysüz 1999). Volcanism and clastic sedimentation are followed by widespread deposition of the pelagic limestone and marl of the Upper Campanian to Upper Palaeocene Akveren Forma- tion (Ketin \& Gümüş 1963; Özcan et al. 2012). The Eocene compressional movements resulting from multiple collisions of small blocks (cf. Şengör \& Yilmaz 1981), which dominated the tectonics of Anatolia, led to pre-Lutetian folding and faulting in the Marmara region. These movements resulted in the thrusting of the Palaeozoic and Mesozoic units over the Upper Cretaceous-Lower Eocene sequences during the early Eocene (Özgül 2011).

\section{TERTIARY}

In the eastern part of Istanbul, Tertiary rocks start with the Upper Palaeocene-Lower Ypresian debris flow deposits which are called the Şile Formation by Baykal \& Önalan (1979). The Şile Formation unconformably overlies the Upper Campanian-Upper Paleocene Akveren Formation and contains limestone blocks from the Akveren Formation. The Şile Formation was deposited on a shore which was tectonically active because of the movement of the Şile Thrust. The east-west striking Şile thrust is probably a back-thrust related to the closing of the northern branch of the Neo-Tethyan Ocean, called the Intra-Pontide Ocean, to the south of Istanbul. Gedik et al. (2005b) give Ypresian (early Cuisian) age based on nannoplankton fossils for the Şile Formation. The Lower Lutetian Yunuslubayır Formation overlies the Şile Formation with angular unconformity. The Yunuslubayır Formation consists of high-energy-environment shallow marine limestones, sandstones and conglomerates. The Yunuslubayır Formation deposited as a result of a transgression after the Şile thrust 


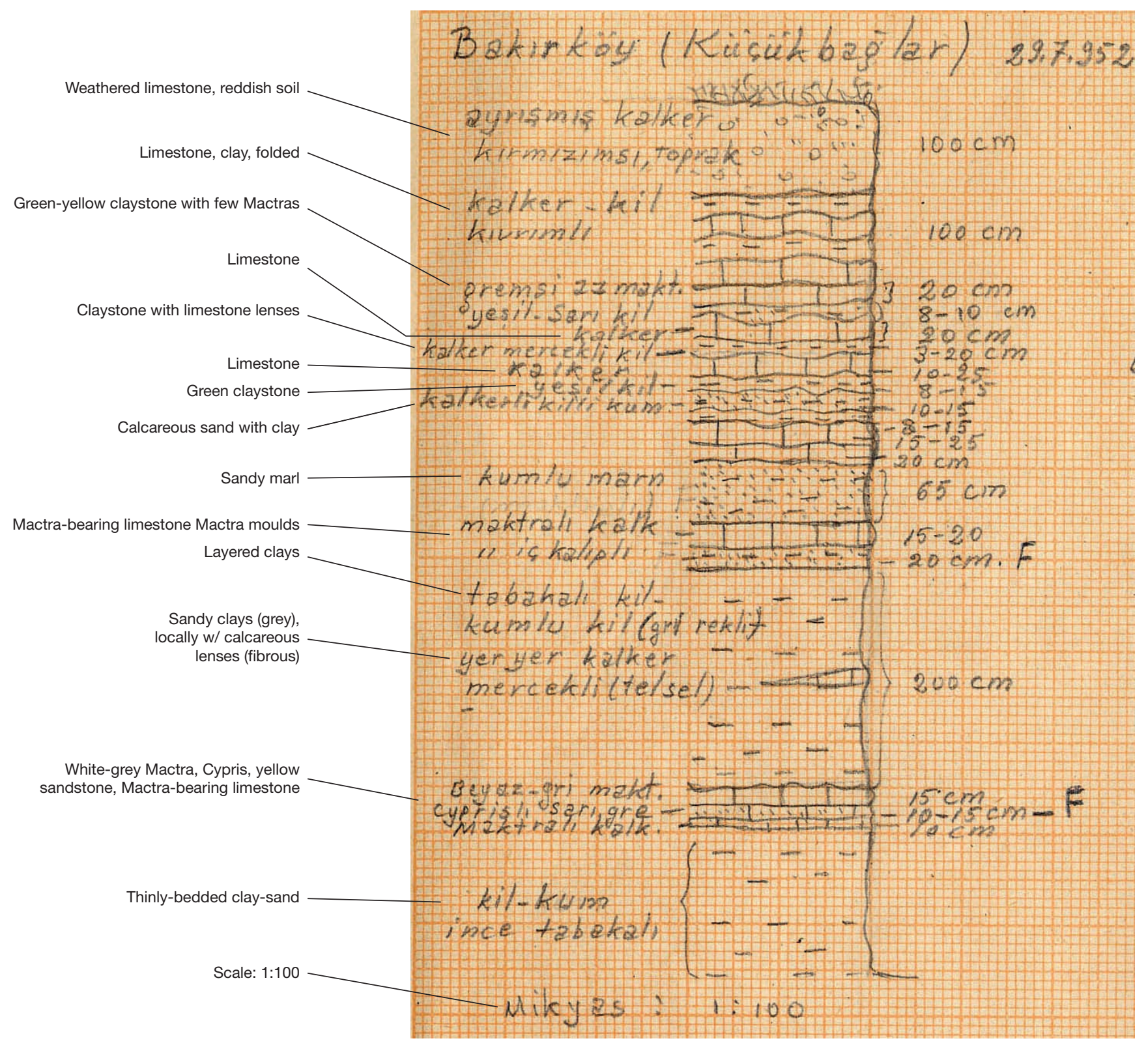

FıG. 8. - Detailed stratigraphic sections from Küçükbağlar, Bakırköy. An original drawing from Cazibe Sayar's collection. Date of the drawing: 23.07.1952.

affected the region. Özcan et al. (2007) report Nummulites laevigatus, N. perforatus, Assilina spira-groups and sporadic tests of orthophragminids represented by Discocyclina archiaci bartholomei from the Yunuslubayır Formation. After the Yunuslubayır had been laid down, there was no deposition until the Pliocene because of a rapid, post-collisional uplift in the region (Fig. 4).

In the west of Istanbul, the main topic of the present monograph, the story was quite different; the sequence starts there by a continental to marine transitional deposits called the Koyunbaba Formation (Keskin 1974) forming a part of the fill of the Thrace Basin. Lutetian-Bartonian benthic foraminifers, echinids (Akartuna 1953), Bartonian Nummulites fabianii, N. incrassatus fossils (Gökçen 1973), Lutetian-Bartonian macrofossils, Upper Lutetian-Priabonian microfossils (Umut et al. 1983), middle-late Eocene palynomorphs (Bat1 et al. 1993, 2002) have been reported, and Özgül (2011) suggested a Lutetian-Priabonian age for the formation. These sandstones and conglomerates with limestone levels were probably deposited on the eastern edge of the Thrace Basin. While transgression continued in the basin, the Koyunbaba Formation was overlain by the reefal Soğucak Limestone first described by Holmes (1961) farther west in Thrace. In Istanbul the Soğucak Limestone is represented by the reef core and fore-reef facies in Şamlar and Çatalca regions in the south, and only by the reef core in Karaburun region in the north (Görür et al. 1981; Sakınç 1994). Less et al. (2011) reported an Upper Bartonian age in this section based on findings of nummulites and orthophragmines. 


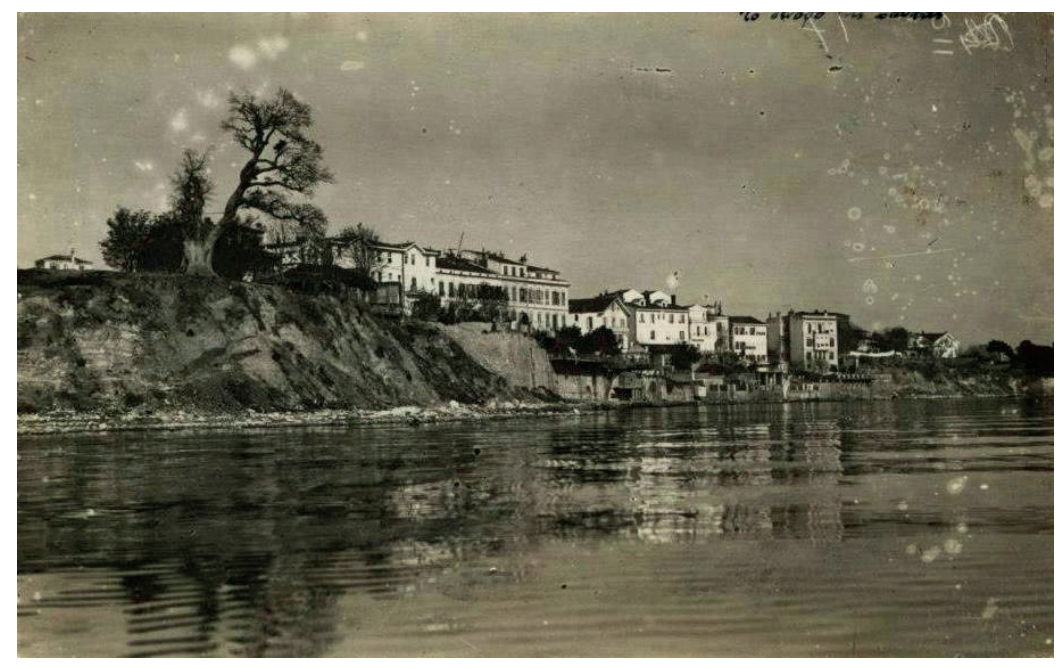

Fıg. 9. - A view from Sakızağacı, Bakırköy area (1932). This photo is taken from http://eski.istanbulium.net.

The Pinarhisar Formation unconformably overlies the Soğucak Formation in the Çatalca region. It starts with a Congeria-rich limestone, the upper parts of which consist of loose sandstones, conglomerates, oolitic limestones and marls. A Lower Oligocene age was suggested for the formation by different studies (Gökçen 1973; Sönmez-Gökçen 1973; Umut et al. 1983, 1984).

In the Karaburun region along the Thracian shores of the Black Sea northwest of Istanbul, the Soğucak Limestone is overlain by the Upper Eocene-Lower Miocene Karaburun Formation, the deposition of which started with a transgression and ended with a regression. It commences with current-bedded conglomerates at the bottom and it continues upwards with sandstone, mudstone, claystone with thin limestone intercalations and finally ends with a claystone with coal layers. Foraminifera such as mainly Nummulites vascus, Catapsydrax dissimilis, Globigerina and coccolithophores such as Dictyococcolites bisectus, Coccolithus eopelagicus are reported in this formation (Sakınç 1994).

The shale and marl deposits with tuff intercalations of the Ceylan Formation overlies the Soğucak Limestone in Şamlar and Çatalca regions. In the inner part of the Thrace Basin, the thickness of the Ceylan Formation is around $1000 \mathrm{~m}$, but on the Istanbul itself, it is thought to be only 150-200 m (Özgül et al. 2005). It represents a low energy/stable depositional environment. The age of the Ceylan Formation in the Istanbul region is given as Priabonian by Akartuna (1953) on the basis of the findings of Nummulites fabianii and Rupelian by Less et al. (2011) based on Nummulites vascus, N. bouillei and Operculina complanata findings. These observations indicate that the age of the Ceylan Formation in the Istanbul region can be determined to be broadly Upper Eocene-Lower Oligocene.

The succeeding Danişmen Formation overlies both the Soğucak and the Ceylan formations unconformably. It was defined in its present form by Ünal (1967) and consists of sandstone, conglomerate, shale with coal beds and tuff intercalations representing flood plain, swamp and lake environments. For the Danişmen Formation a commonly- accepted age is Upper Oligocene-Lower Miocene (Gökçen 1971; Kasar \& Eren 1986; Alişan \& Gerhard 1987; Saraç 1987; Akyol \& Akgün 1995) which in Istanbul heralds the Paratethyan history here.

With the onset of the medial Miocene a completely different regime becomes established in the western part of Istanbul. The vanishing of the Neo-Tethys as a result of the northward drift of India and Australia, and of the simultaneous counterclockwise rotations involving several microplates in the Mediterranean area, led to the formation of the Alpine-Himalayan orogenic belt (Alpides) on the southern periphery of Eurasia. At the Eocene/Oligocene boundary, this closure gave rise to the birth of several basins of various sizes between the stable Eurasian platform and the relicts of the western Tethys, including the Eastern Mediterranean and the Paratethys Seas. Spratt (1857) was the first to distinguish a fresh water lake by examining the deposits in the Euboean and Locrian coasts in Greece. He pointed out the resemblance of these deposits to the Dardanelles and the Sea of Marmara, and argued that together they formed a great ancient oriental lake from Miocene to Pliocene. Ami Boué also recognised the peculiarity of the Istanbul Miocene, but did not relate it to the similar rocks farther to the northwest as far north as Vienna, except to note their similarity in rock type and age. Later on, Eduard Suess (1866) recognised what was later named as Paratethys as a biogeographic entity differing from the Neogene Mediterranean on the basis of the well-recognized late Neogene evolution of endemic mollusc faunas in the Vienna, Pannonian, Styrian, Dacian and Euxinian basins (Rögl 1999; Steininger \& Wessely 1999; Piller et al. 2007). The Paratethys, first named by the Russian geologist Vladimir Dmitrievich Laskarev (1924), occupied a large area between the Rhône Basin in France and the Aral Sea in the Inner Asia. The Paratethys was subdivided into three parts, the Western, Central and Eastern Paratethys respectively, according to the different ecosystems along its length. The Western Paratethys, covers the Alpine Foreland Basins of France, Switzerland, South Germany and Upper Austria, The Central Paratethys includes the Eastern 


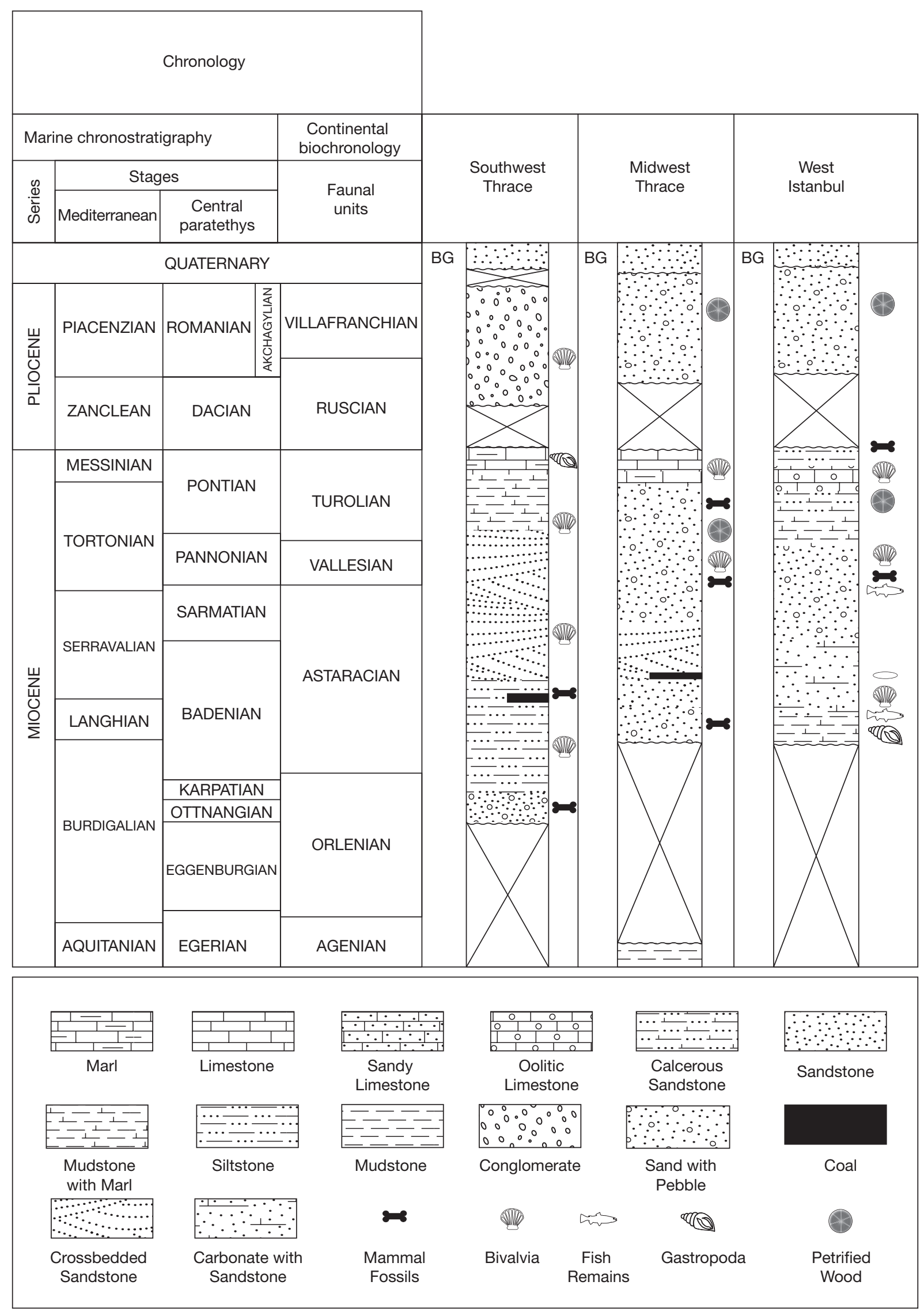

FIG. 10. - Correlation of the Neogene stratigraphy of the Istanbul region with the Thrace Basin. Modified from Sakınç et al. (1999, 2007). 


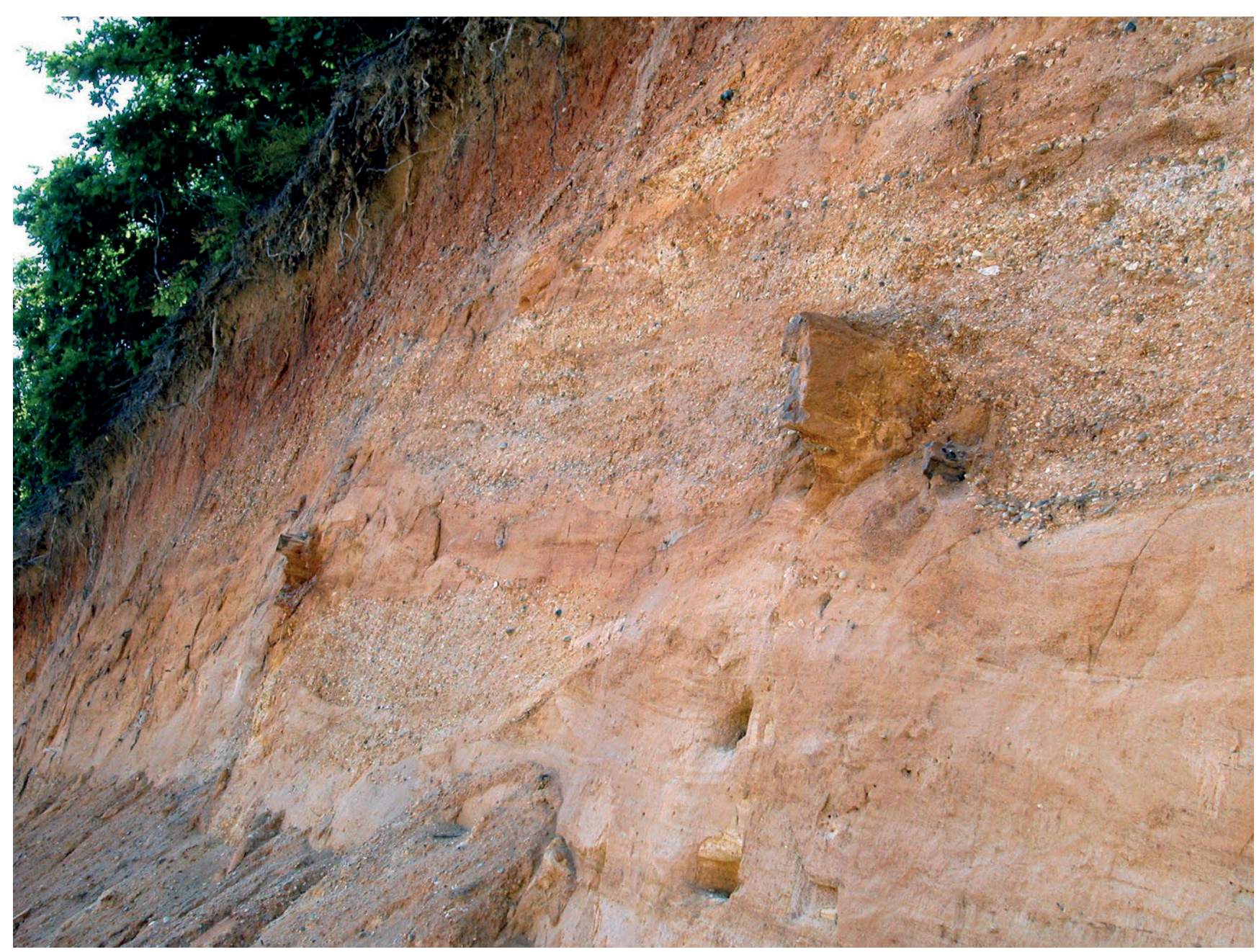

FIG. 11. - Petrified woods in the Ergene Formation, Karacaköy, Istanbul.

Alpine - Carpathian Foreland basins, from Lower Austria to Moldavia, and the Pannonian Basin System. The Eastern Paratethys comprises the Euxinian (Black Sea), Caspian and Aral Sea basins (Piller et al. 2007). Istanbul is considered as a part of Central Paratethys.

There was no deposition in the west until the Paratethys covered the region in the Badenian. Miocene rocks overlie the open-folded Oligocene rocks with angular unconformity. Sandstones with marl intercalations of the Çamurluhan Formation lie over the Palaeozoic basement unconformably (Sayar 1987). Marine mollusc fossils in this formation can be compared with the Baden beds of the Vienna Basin (Chaput 1936). The Çamurluhan Formation is unconformably overlain by the Çukurçeşme Formation of the Çekmece Group.

The Çekmece Group (Figs 5, 6, 7, 8, 9) consists of river, lagoon and brackish water deposits and contains three formations: Çukurçeşme, Güngören and Bakırköy. This group and its formations were first named in Sayar (1987), whom we here follow. Current-bedded, loose sandstones with mica flakes represents the Çukurçeşme Fomation. Its thickness is given as 30-40 m by Özgül (2011). Malik \& Nafiz (1933) reported from the site of Küçükçekmece, which is included in the Çukurçeşme Fomation, a rich vertebrate fauna composed of terrestrial and marine elements such as "Dinotherium sp., Mastodon sp., Mastodon pentelici Gaudry \& Lartet, 1856, Aceratherium sp., Rhinoceros pachygnatus Wagner, 1848, Hipparion gracile de Christol, 1832, Sus erymanthius Roth \& Wagner, 1854, Camelopardalis attica Gaudry \& Lartet, 1856, Orasius speciosus Wagner, 1861, Helicotragus rotundicornis (Weithofer, 1890), Tragocerus amaltheus (Roth \& Wagner, 1861), Palaeoreas Lindermayeri (Wagner, 1848), Dorcatherium Puyhauberti Arambourg \& Piveteau, 1929, Gazella gaudryi Schlosser, 1903, Gazella strylodondis (species name unknown in the literature), Mustela pentelici Gaudry, 1861, Lutra sp., Ictitherium sp., Ursavus sp., Mochoerodus orientalis Kittl, 1887, Steneofiber sp., Phoca sp., Delphinus sp., reptiles and fishes" (see also Arıç 1955). The palaeontology chapters in the present volume restudy the systematics of all mammalian taxa from Küçükçekmece.

The Güngören Formation consists of current-bedded sandstone-shale intercalations with plant fragments and its thickness is around 120-140 m (Özgül 2011). The Bakırköy Formation consists of marls and limestones with macrofossil fragments. In the Bakırköy Formation the fossils of Mactra podolica Eichwald, 1853, M. bulgarica Toula, 1909, M. bulgarica var. 
Late early-early middle Miocene 22-15 Ma Aragonian/Badenian

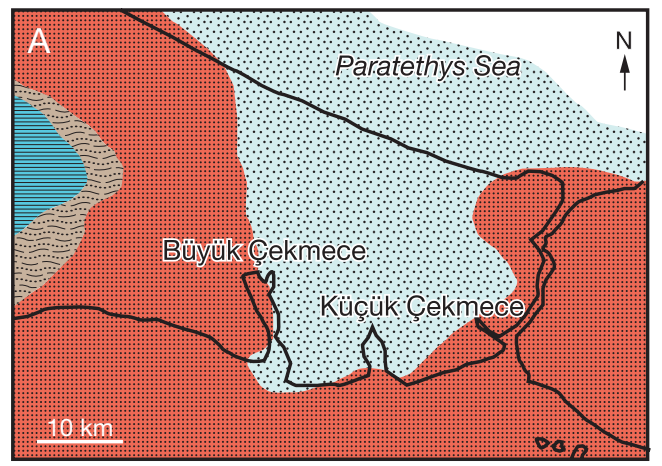

Late Miocene 10-5 Ma

Turolian/Panonian-Pontian

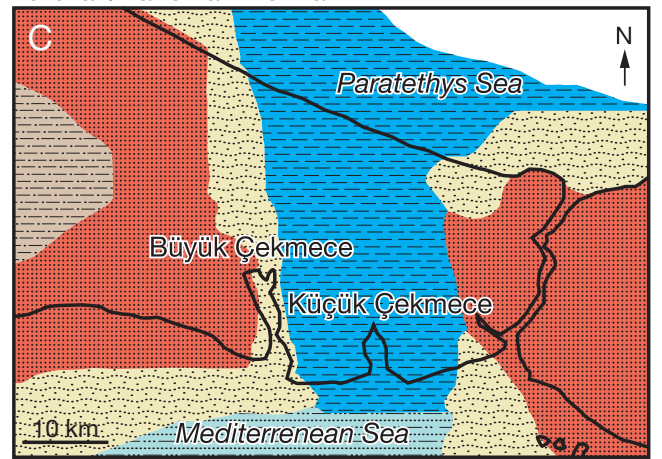

Late middle-early Miocene 14-10 Ma Serravalian/Vallesian

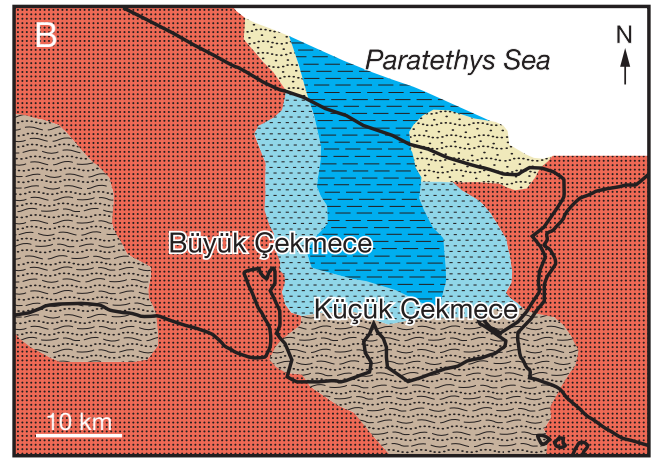

Late Pliocene 3-1.7 Ma

Piacenzian/Akchagylian

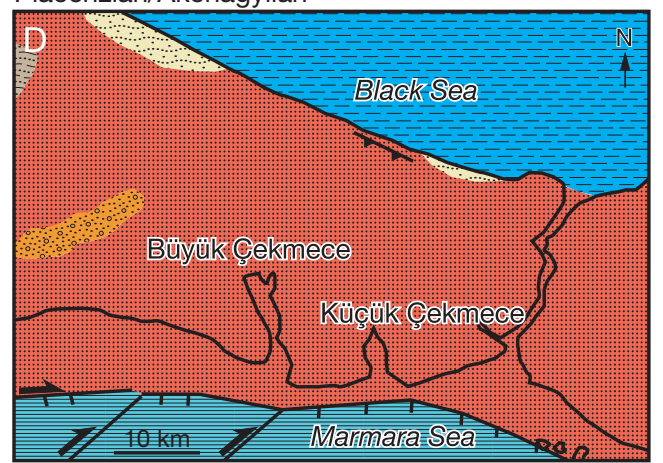

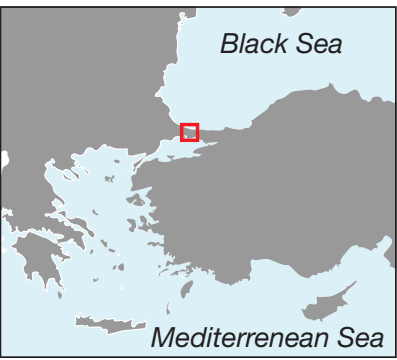

Lacustrine Area

Marine Shelf Area

(Paratethys)

Beach/Dunes Area

Marine Area

Endemic Marine Area

Braided River Area

Erosional Area

Brackish Marine Area

Meandering River Area

Alluvial Fan Area

FIG. 12. - Paleogeographic maps of the Istanbul region. Modified from Sakınç et al. (1999): A, Aragonian/Badenian; B, Serravalian/Vallesian; C, Turolian/PanonianPontian; D, Piacenzian/Akchagylian.

nalivkini Kolesnikov, 1929, M. bulgarica var. inflata Kolesnikov, 1929, M. cf. podolica Eichwald, 1830, M. (Spisula) subtruncata De Costa var. triangula Brocchi, 1814, M. caspia Eichwald, 1830, M. firma Zhizhchenko, 1936, M. caspia var. acuminata Zhizhchenko, 1936, Melanopsis trojana Hoernes, 1877, Unio (Psilunio) istanbulensis Chaput \& Gillet, 1939, U. (Psilunio) carenautus L. Erentöz, 1956, Thedoxus sp., Helix (Helix) cf. marazeci Sevastos, 1903, Mastodon sp., Hipparion sp., Trionix sp. are reported (Chaput \& Gillet 1939; Gillet et al. 1978). On the basis of these fossils, the age of the Çekmece Group is established as Upper Vallesian (between 10 and $8 \mathrm{Ma}$, Tortonian = Pannonian: Sen $\&$ Steininger written comm. 2013). These animals were living along the southern shores of the Paratethys Sea with the brackish waters during the time of deposition of the Çekmece Group (Figs 6, 7, 8, 9).

In the west in the Thrace Basin, the Ergene Formation, which contains petrified woods, represents an equivalent of the Çekmece Group. The Ergene Formation (Figs 10;11) extends in the western part of Istanbul near Küçükçekmece and the petrified woods can be found even there. Palaeogeographically, there is a transition between these petrified woods and the mammal-bearing horizon of the Çekmece Group (Sakınç et al. 2007).

During Badenian time west of Istanbul was a marine shelf of the Paratethys. West of Büyükçekmece, the region was covered by the river systems and deposits of Çamurluhan
Formation at the same time (Fig. 12A). With the invasion of the Küçükçekmece region by Paratethys Sea, marine bivalves emerge on the shores. On the land the mammals were wandering in an ecosystem similar to modern day African savannah (Fig. 12B). In the Pontian time, the Paratethys was connected with the Mediterrenean Sea. The region remained as a marine area until the late Pliocene (Fig. 12C). With the arrival of the North Anatolian Fault Zone, the region was uplifted and became an erosional area (Fig. 12D) (Sakınç et al. 1999).

Pliocene-Pleistocene deposits in Istanbul were defined by von Hochstetter (1870) as a "Thracian Stage" and defined by Penck (1919) as the "Belgrad gravels", after the nearby village called Belgrad. These deposits are correlated with the Belvedere gravels in Vienna (von Hochstetter 1870). These river deposits unconformably overlies the Çekmece Group and contains petrified woods fragments. Now that the Belvedere Gravels are known to be entirely Quaternary, the Belgrad gravels may also be entirely Quaternary, but there is no direct observation to support this as yet, except to say that they lie on the Thracian-Bythinian erosion surface (Cvijić 1906; for a summary in German, see Cvijić 1908).

Both the east and the west of the city is covered by PliocenePleistocene river deposits that are deposited on tilted surfaces. The geomorphology of Istanbul is controlled by the torsion of the erosion surface which resulted in creating the present drainage. The drainage divide of the rivers is close to the Black 


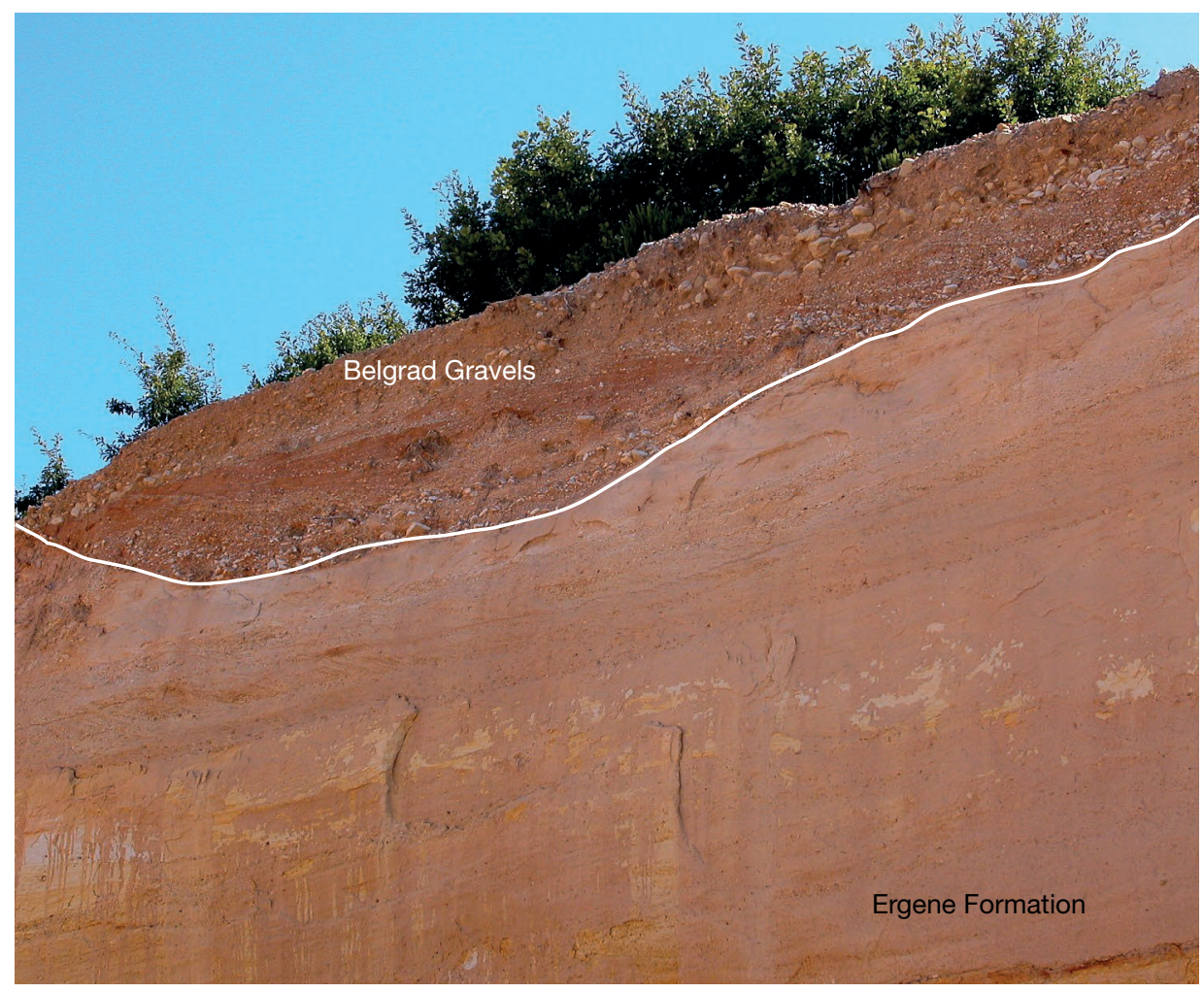

FIG. 13. - Belgrad conglomerates, Karacaköy, Istanbul.

Sea to the west of the Bosphorus and close to the Marmara Sea to the east of the Bosphorus, a fact first noted by the Serbian geographer Jovan Cvijić (1906, 1908). The location of the water divide controlled where the Bosphorus would form. It is hard to erode the water divides which are close to the shore and high in altitude in such a warm and dry climate at that time. Because of this, the water divide where the Bosphorus would form, was denuded faster than the water divides closer to the shores of the Black and the Marmara seas, because it was already low. Thus, valleys where the Bosphorus is located, were preferred by the sea as it rose by $100 \mathrm{~m}$ at the end of the last ice age (Şengör 2011) (Fig. 13).

\section{CONCLUSIONS}

The geology of the city and the province of Istanbul is extraordinarily complex for such a small area. In it we have records of three major orogenies: Hercynian (or Scythide) during the late Palaeozoic, Cimmeride during the latest Triassic to the early Cretaceous and Alpide, from the late Cretaceous to the present-day. The late Cainozoic sedimentary layers containing the fossils described in the present volume were laid down at a time when the orogenic effects of the closure of the northern branch of the Neo-Tethys were no longer being felt here and the Paratethys had sent a narrow bay into the western areas of Istanbul. These rocks underlie much of the Old Byzantium and Constantinople as already surmised by von Hochstetter (1870) and largely corroborated by Cvijić
(1906, 1908). The marine animals of Miocene time we see in Istanbul lived in that bay and the land animals around that gulf. The gulf extended into the Dardanelles and there we see a mixture of the Paratethyan waters with those of the Mediterranean. The great confusion that has so far reigned on the stratigraphy of the Istanbul area and its correlation with the surrounding regions has resulted mainly from a lack of discipline in stratigraphic name-giving.

\section{Acknowledgements}

This study was supported by TÜBİTAK Project 113 Y081. We thank Daniel Bernoulli and Necdet Özgül for their contributions and reviewers Olivier Monod and Timur Ustaömer for their detailed and constructive comments on our manuscript, and Sevket Sen for editing process.

\section{REFERENCES}

AbDÜsSelÂMoĞLU M. Ş. 1963. - Nouvelles observations stratigraphiques et paléontologiques sur les terrains paléozoiques affleurant à l'est du Bosphore. Bulletin of the Mineral Research and Exploration Institute of Turkey 60: 1-6 + 1 pl.

ABDÜSSELÂMOĞLU M. Ş. 1977. — The Palaeozoic and Mesozoic in the Gebze region; explanatory text and excursion guidebook. 4 th Colloquium on the Aegean Region, Excursion. 4: Western Anatolia and Thrace. İstanbul Teknik Universitesi, Maden Fakültesi, Istanbul, 16 p.

AKARTUNA M. 1953. - Çatalca - Karacaköy bölgesinin jeolojisi hakkında. İstanbul Üniversitesi Fen Fakültesi Mecmuasi B XIII: 183-204. 
AKYOl E. \& AKGÜN E. 1995. — Trakya karasal Tersiyer'inde yaş tayinleri. Trakya Havzası Jeolojisi Sempozyumu, LüleburgazKırklareli: 28.

AlișAn C. \& Gerhard J. E. 1987. — Kuzey Trakya Havzasında açılan üç kuyunun palinostratigrafisi ve kaynak kaya özellikleri, 7. Petrol Kongresi. Türkiye Petrol Jeologları Derneği: 461-474.

Altinlı E. 1968. - İzmit-Hereke-Kurcadağ alanının jeoloji incelemesi. Maden Tetkik ve Arama Enstitüsü Dergisi 71: 1-26.

Altinli I. E., SoYTÜRK N. \& SAKA K. 1970. — Hereke-Tavşancıl-Tepecik alanının jeolojisi. İstanbul Üniversitesi Fen Fakültesi Mecmuası B 35 (1-2): 69-75.

ARIÇ C. 1955. - İstanbul Paleozoyik arazisinde bulunan oolitli ve fosilli demir madeni. Istanbul Teknik Üniversitesi Dergisi II (3-4): 67, 68.

ARPAT E. 1978. - Safranbolu Yöresinde Kambriyen-Devoniyen istifi. Türkiye Jeoloji Kurumu 32. Bilimsel ve Teknik Kurultay, Bildiri Özetleri: 67, 68 .

ARTHABer G. E. vON 1914. — Die Trias von Bithynien (Anatolien). Beiträge zur Paläontologie und Geologie Österreich-Ungarns und des Orients 27: 87-206, pls XI-XVIII.

Aysal N., Keskin M., PeYtcheva I., Duru O. \& AKgündüz S. 2015. - Geochronology, geochemistry and isotope systematics of a mafic intermediate dyke complex in the Istanbul zone, northern Turkey. Goldschmidt 2015 Abstracts: 155.

BABIN C. 1973. - Bivalvia of the Kartal formation of Devonian age, Paleozoic of Istanbul. Ege Üniversitesi Fen Fakültesi Kitaplar Serisi 40: 37-89.

BATı Z., ERK S. \& AKÇA N. 1993. — Trakya Havzası Tersiyer birimlerinin palinomorf, foraminifer ve nannoplankton biyostratigrafisi, Teknik rapor. TPAO Araştırma Grubu Arşivi, 92 p.

Bati Z. A., Ediger V. S., Teymur S., AKÇa N., SANCay H., ERTUĞ K., Kirici S., EREnler M. \& AKÖZ Ö. 2002. — Kuzey Trakya Havzası'nın Palinomorf, Foraminifer ve Nannoplankton Biyostratigrafisi. Türkiye Stratigrafi Komitesi Çalıștayz: 14.

BAYKal A. F. \& ÖNALAN M. 1979. — Şile Sedimanter Karmaşığı (Sile Olistostromu). Altınlı Sempozyumu Tebliğler Kitabı. İstanbul Üniversitesi Yerbilimleri Fakültesi: 15-25.

Boué A. 1840. — La Turquie de l'Europe ou observations sur la géographie, la géologie, l'histoire naturelle, la statistique, les mœurs, les coutumes, l'archéologie, l'agriculture, l'industrie, le commerce, les gouvernements divers, le clergé, l'histoire et l'état politique de cet empire. Tome premier (première partie - partie de géographie, de géologie et d'histoire naturelle). Arthus Bertrand, Paris, XVII + 523 p. +1 foldout map.

BÜRKÜT Y. 1966. - Kuzeybatı Anadolu'da yeralan plütonların mukayeseli-jenetik etüdü. PhD thesis, İTÜ Maden Fakültesi, İstanbul, $272 \mathrm{p}$.

Çắlayan M. A. \& Yurtsever A. 1998. — 1:100,000 Ölçekli Türkiye Jeoloji Haritaları, no. 20, 21, 22, 23, Burgaz-A3, Edirne-B2 ve B3, Burgaz-A4 ve Kırklareli-B4; Kırklareli-B5 ve B6; Kırklareli-C6 Paftaları [Geological Map of Turkey at 1: 100,000 Scale, no. 20, 21, 22, 23, Burgaz-A3, Edirne-B2 ve B3, Burgaz-A4 ve Kırklareli-B4; Kırklareli-B5 ve B6; Kırklareli-C6 Sheets]. Mineral Research and Exploration Institute (MTA) of Turkey Publications (in Turkish with English abstract).

CARLS P. 1973. - Strophomenids of the Lower Devonian Kartal formation, Istanbul, Paleozoic of Istanbul. Ege Üniversitesi Fen Fakültesi Kitaplar Serisi 40: 90-94.

Chaput E. 1936. - Voyages d'études géologiques et géomorphogéniques en Turquie. Mémoires de l'Institut d'Archéologie de Stamboul, II. E. De Boccard, Paris, VIII+312 p., 27 pls.

Chaput E. \& Gillet S. 1939. - Les faunes de mollusques des terrains à Hipparion gracile de Küçükçekmece près d'Istanbul (Turquie). Bulletin de la Société géologique de France 5e série, 8: 363-388.

Chaput E. \& Hovasse R. 1930. - Notice préliminaire sur le Crétacé supérieur de Zekerie Köy, au Nord de Constantinople. Bulletin de la Faculté des Sciences de Stamboul 4: 1-16, 1 map.
Chen F., Siebel W., Satir M., TerzioĞlu M. \& Saka K. 2002. Geochronology of the Karadere basement (NW Turkey) and implications for the geological evolution of the Istanbul zone. International Journal of Earth Sciences 91: 469-481.

CVIJIĆ J. 1906. - Fundamentals of the Geology and Geography of Macedonia and Old Serbia - Travels in Southern Bulgaria, Thrace, some parts of Asia Minor, Thessaly, Epirus and Northern Albania. Serbian Royal Academy, printing House of the Serbian Royal Academy, Belgrade, first book VIII + 392 p.; second book: 393-688 + Errata+many unnumbered photographic plates +2 atlases: 1. Geological Atlas of Macedonia and Old Serbia; 2. Lakes of Macedonia, Old Serbia and Epirus [in Serbian].

CVIJIĆ J. 1908. — Grundlinien der Geographie und Geologie von Mazedonien und Altserbien nebst Beobachtungen in Thrazien, Thessalien, Epirus und Nordalbanien. Ergänzungsheft Nr. 162 zu Petermanns Mitteilungen, Justus Perthes, Gotha, VIII + 392 p. 16 pls, 2 foldout maps.

DAĞER Z. 1980. — Les foraminiferes du Trias de la Péninsula de Kocaeli, Turquie. PhD thesis, University of Geneva, Switzerland, $47 \mathrm{p}$.

Dean W., Monod O., Rickards R., Demir O. \& BulTYNCK P. 2000. - Lower Palaeozoic stratigraphy and palaeontology, Karadere-Zirze area, Pontus mountains, northern Turkey. Geological Magazine 137: 555-582.

Dojen C., ÖzGÜl N., GÖNCÜOGLU Y. \& GöncÜOglu M. C. 2004. - Early Devonian ostracodes of Thuringian ecotype from NW Anatolia (Turkey). Neues Jahrbuch für Geologie und Palaontologie-Monatshefte 12: 733-748.

ENDRISS W. 1910. - Quer durch die Bithynische Halbinsel. Petermans geographische Mitteilungen 2 (4): 177-181.

ERGUVANLI K. 1947. - Kocaeli Triasinda yeni fosil yataklari; New fossiliferous beds in Kocaeli Triassic formations. Turkiye Jeoloji Kurumu Bülteni (Bulletin of the Geological Society of Turkey) 1 (1): 158-163. Year 6, no 4: 1-16.

ERGUVANLI K. 1949. - Hereke pudingleri ile Gebze tașlarının inşaat bakımından etüdü ve civarlarının jeolojisi. $\mathrm{PhD}$ Thesis, Technical University of Istanbul, 89 p.

GANDL J. 1973. - Trilobites from the Devonian of Istanbul, Paleozoic of Istanbul. Ege Üniversitesi Fen Fakültesi Kitaplar Serisi 40: 95-96.

GEDIK İ. 1975. - Die Conodonten der Trias auf der Kocaeli-Halbinsel (Türkei). Palaoentographica A150: 99-160.

Gedik İ., Timur E., Duru M., Alan İ., Pehlivan S., Altun İ., AKBAS B., ÖNALAN M. \& ÖZCAN İ. 2002. - İstanbul Paleozoik istifinde Kocatöngel ve Bakacak formasyonları. 55. Türkiye Jeoloji Kurultayı JMO, Ankara: 97-99.

Gedik İ., Pehlivan Ş., Timur E., Duru Altun İ., Akbaş B., ÖZCAN İ. \& AlAN İ. 2005a. - Kocaeli Yarmmadasinın Jeolojisi [Geology of Kocaeli Peninsula]. Mineral Research and Exploration Institue (MTA) of Turkey Report no. 10774 (in Turkish, unpublished).

GediK İ., Timur E., Duru M. \& Pehlivan S. 2005b. - 1:50 000 ölçekli Türkiye Jeoloji Haritaları No: 10 İstanbul - F 22d paftası. Maden Tetkik ve Arama Genel Müdürlü̈̆̈̈ Jeoloji Etütleri Dairesi: 1-49, 1 foldout map.

Gillet S., Gramann F. Steffens P. \& Benda L. 1978. - Neue biostratigraphische Ergebnisse aus dem brackischen Neogen an Dardanellen und Marmara-Meer (Türkei). Newsletters on Stratigraphy 7: 53-64.

GoCEV P. M. 1979. - The place of the Strandzha Mountains in the Alpine structure of the Balkan Peninsula. Spisanie na Bulgarskogo Geologichesko Druzhestvo 40 (1): 27-46.

GOCEV P. M. 1991 - Some problems of the nappe tectonics of the Strandzhides in Bulgaria and Turkey. Bulletin of the Technical University of Istanbul 44: 137-164.

GÖKÇEN N. 1971. — Güneydoğu Trakyảnın Paleojen stratigrafisinde ostracodlar açısından yeni görüşler. 1. Türkiye Petrol Kongresi (Proceedings of the Turkish 1st Petroleum Congress), 17-19 December, Ankara: 81-85.

GÖKÇEN N. 1973. — Pınarhisar Formasyonu'nun yaşı ve ortam 
sartlarında görülen yanal değişimler (Kuzey, Kuzeydoğu Trakya). Cumburiyetin 50. Yilu Yerbilimleri Kongresi, Maden Tetkik ve Arama Enstitüsü, Ankara: 128-142.

GÖNCÜOĞLu M. C., ÖZgül N., Gedì İ., OKuyucu C., SAYdam G. D., Timur E., Yanev S., Boncheva I., LaKova I., SACHJanSKI V. \& MALIAKOV Y. 2006. - Bulgaristan ve KB Türkiye'deki tektonik birliklerin Paleozoyik istifleri ve korelasyonu [Palaeozoic sequences and correlation of tectonic units in Bulgaria and NW Turkey]. Mineral Research and Exploration Institute (MTA) of Turkey, Report no. 10884 (in Turkish, unpublished).

GÖRÜR N., AKKÖK R., SEYMEN L., ALKAYA F. \& OKTAY F. Y. 1981. Trakya Havzası doğusunda Eosen resifleri. İstanbul Yerbilimleri $2(3-4): 303-306$.

GÖrÜr N., Monod O., OKay A. I., SengÖr C., TÜYsÜz O., YigITBAS E., SAKINÇ M. \& AKKÖK R. 1997. — Palaeogeographic and tectonic position of the Carboniferous rocks of the western Pontides (Turkey) in the frame of the Variscan belt. Bulletin de la Société géologique de France 168: 197-206.

HAAS W. 1968. - Das Alt-Paläozoikum von Bithynien (Nordwest Türkei). Neues Jahrbuch für Geologie und Paläontologie, Abhandlungen 131: 178-242.

HochSTETTER F. R. vON 1870. — Die geologischen Verhaeltnisse des östlichen Teiles der Europischen Turkei. Jahrbuch der $k . k$. geologischen Reichftanstalt 20 (3): 372-388.

Holmes A. 1961. - A stratigraphic review of Thrace. Turkish Petroleum Corporation unpublished technical report 368: 1-56.

KASAR S. \& EREN A. 1986. - Kırklareli-Saray-Kıyıköy bölgesinin jeolojisi. Turkish Petroleum Corporation, Report.

KaYA O. 1973. - The Devonian and Lower Carboniferous stratigraphy of the İstinye, Bostancı and Büyükada subareas, in KaYA O. (ed.), Paleozoic of Istanbul. Ege Universitesi Fen Fakültesi Kitaplar Serisi 40: 1-36.

KAYA O. 1978. - İstanbul Ordovisyeni ve Siluriyeni. Yerbilimleri, Hacettepe Üniversitesi Yerbilimleri Enstitüsü 4: 1-22.

KAYA O. \& MAMET B. 1971. - Biostratigraphy of the Visean Cebecikoy Limestone near Istanbul, Turkey. The Journal of Foraminiferal Research 1: 77-80.

KAYA O. \& LYS M. 1979-1980. - Triassic on the western side of Bosphorus (Kilyos, Istanbul): a Recent Discovery. Bulletin of the Mineral Research and Exploration Institute of Turkey 93-94: 20-26.

Kaya O., Weidmann J., Kozur H., ÖZdemir Ü., ÖZer S. \& BeaUVAIS L. 1987. - A new discovery of the Lower Cretaceous in Istanbul, Turkey. Bulletin of the Mineral Research and Exploration Institute of Turkey 107: 106-111.

KeSKIN C. 1974. - Kuzey Ergene havzasının stratigrafisi. Türkiye 2. Petrol Kongresi (Proceedings of the Turkish 2nd Petroleum Congress): $154-163$.

KESKIN M. \& TÜYSÜZ O. 1999. - Geochemical evidence for nature and evolution of the rift volcanism related to the opening of the Black Sea, Central Pontides, Turkey. European Union of Geosciences, EUG10 in Strasbourg, Journal of Conference Abstracts, 4: 816.

KeTiN İ. 1959. - Türkiye' nin orojenik gelişmesi. Maden Tetkik ve Arama Dergisi 53: 78-86.

KeTiN İ. 1982. - Genel Jeoloji. İTÜ Maden Fakültesi Yayınları, İstanbul, Vol. 2, 216 p.

KeTiN İ. \& GÜMÜs Ö. 1963. - Sinop-Ayancık arasında III. bölgeye dahil sahaların jeolojisi. Turkish Petroleum Corporation, unpublished technical report 288, $118 \mathrm{p}$.

LASKAREV V. 1924. - Sur les équivalents du Sarmatien supérieur en Serbie, in Vujević P. (ed.), Recueil de travaux offert à M. Jovan Cvijic par ses amis et collaborateurs. Drzhavna Shtamparija, Beograd, 73-85.

LESS G., ÖZCAN E. \& OKAY A. I. 2011. — Stratigraphy and larger foraminifera of the Middle Eocene to Lower Oligocene shallowmarine units in the northern and eastern parts of the Thrace Basin, NW Turkey. Turkish Journal of Earth Sciences 20: 793-845.

MaliK A. \& Nafiz H. 1933. - Vertébrés fossiles de Küçük Cekmece. Bulletin de la Faculté des Sciences de l'Université d'Istanbul 8: 1-119.
MAMET B. 1973. - Foraminiferal biostratigraphy of the Lower Carboniferous Trakya and Heybeliada formations, Istanbul region, Turkey. Paleozoic of Istanbul. Ege Universitesi, Fen Fakültesi, Kitaplar Serisi 40: 137-143.

Natal'In B. A. \& ŞENGÖR A. M. C. 2005. — Late Palaeozoic to Triassic evolution of the Turan and Scythian platforms: the prehistory of the Palaeo-Tethyan closure. Tectonophysics 404: 175-202.

Natal'in B. A., Sunal G., Satir M. \& Toraman E. 2012. - Tectonics of the Strandja Massif, NW Turkey: History of a long-lived arc at the northern margin of Palaeo-Tethys. Turkish Journal of Earth Sciences 21: 755-798.

Nicora A. 1973. - Anisian conodonts from the Gebze area Turkey. Geological Society of America, Abstracts with Programs 5 (4): 341-342.

Noble P. J., Tekin U. K., Gedí İ. \& Pehlivan S. 2008. — Middle to Upper Tournasian Radiolaria of the Baltalimani Formation, Istanbul, Turkey. Journal of Paleontology 82 (1): 37-56.

OKAY A. I. \& NiKISHIN A. M. 2015. - Tectonic evolution of the southern margin of Laurasia in the Black Sea region. International Geology Review 57 (5-8): 1051-1076. http://10.1080/00 206814.2015.1010609

OKay A. I., SATiR M., TÜysüz O., AKyÜZ S. \& Chen F. 2001. — The tectonics of the Strandja Massif: late-Variscan and mid-Mesozoic deformation and metamorphism in the northern Aegean. International Journal of Earth Sciences 90 (2): 217-233.

OKAY N., ZACK T., OKAY A. I. \& BARTH M. 2011. - Sinistral transport along the Trans-European Suture Zone: detrital zircon-rutile geochronology and sandstone petrography from the Carboniferous flysch of the Pontides. Geological Magazine 148 (3): 380-403.

Olivier G. A. 1801. — Voyage dans l'Empire Othoman, l'Égypte et la Perse. Tome premier. H. Agasse, Paris, xii + 432 p.

Önalan M. 1981. - Pendik Bölgesi ile Adalarn Jeolojisi ve Sedimenter Özellikleri [Geology and Sedimentary Characteristics of Pendik Region and Islands]. Dissertation Thesis, İstanbul Üniversitesi (in Turkish, unpublished).

ÖzCAN E., Less G. \& KerTEsz B. 2007. — Late Ypresian to Middle Lutetian orthophragminid record from central and northern Turkey: taxonomy and remarks on zonal scheme. Turkish Journal of Earth Sciences 16: 281-318.

Özcan Z., OKay A., Özcan E., Hakyemez A. \& Altiner S. 2012. - Late Cretaceous-Eocene geological evolution of the Pontides based on new stratigraphic and palaeontologic data between the Black Sea coast and Bursa (NW Turkey). Turkish Journal of Earth Sciences 21 (6): 933-960.

ÖZGÜL N. 2011. - Ístanbul İl Alanının Jeolojisi. İstanbul Büyükşehir Belediyesi, Planlama ve İmar Daire Başkanlığı Zemin ve Deprem İnceleme Müdürlüğü, İstanbul, ix+89 p.

ÖZGÜL N. 2012. - Stratigraphy and some structural features of the Istanbul Paleozoic. Turkish Journal of Earth Sciences 21: 817-866. ÖzGÜl N., ÜNer K. BILgin İ. ÖZCAN İ. KorkMaz R., AKMEȘE İ., Yildiz Z., YILDIRIM Ü., AKDAĞ Ö. \& TEKIN M. 2005. — İstanbul İli Temel Jeolojik Özellikleri. İstanbul Büyükșehir, Belediyesi Planlama ve İmar Daire Başkanlığı, 80 p.

ÖzGÜl N., AKDENIZ N., Bilgin R., DAlKILIÇ A. \& GediK İ. 2009. İstanbul'un Kadıköy-Üsküdar ilçeleri ile Kocaeli il sınırı arasında kalan doğu kesiminin jeolojisi. İ.B.B. Deprem Risk Yönetimi ve Kentsel Iyileştirme Daire Başkanlığı, 216 p.

PaeckelmanN W. 1925. - Beitrage zur Kenntnis der Devons am Bosporus, insbesondere in Bithynien. Abhandlungen Preussischen Geologischen Landesanstalt N.F. 98: 1-150.

PaeCKelMANN W. 1938. — Neue Beitrage zur Kenntnis des Geologie, Palaontologie und Petrographie der Umgegend von Konstantinople 2. Geologie Thraziens, Bithyniens und der Prinzeninseln. Abhandlungen Preussischen Geologischen Landesanstalt N.F. 168: 1-202.

PAMIR H. N. \& BAYKAL F. 1947. - Istranca masifinin jeolojik etüdü. MTA Report no. 2257 (unpublished).

PENCK W. 1919. — Grudzüge der Geologie des Bosporus: Veröffentlichungen des Instituts für Meereskunde an der Universität 
Berlin, neue Folge A. Geographisch-naturwissenschaftliche Reihe 4: 1-71, 1 pl.

Piller W. E., Harzhauser M. \& Mandic O. 2007. — Miocene Central Paratethys stratigraphy-current status and future directions. Stratigraphy 4 (2/3): 151-168.

RÖGL F. 1999. - Mediterranean and Paratethys. Facts and hypotheses of an Oligocene to Miocene paleogeography (short overview). Geologica Carpathica 50 (4): 339-349.

SAKINÇ M. 1994. — Karaburun (B Istanbul) denizel Oligoseninin stratigrafisi ve paleontolojisi. Maden Tetkik ve Arama Dergisi 116: 9-14.

SAKinÇ M., Yaltirak C. \& OKTAY F. . 1999. — Palaeogeographical evolution of the Thrace Basin and the Tethys-Paratethys relations at northwestern Turkey (Thrace). Palaeogeography, Palaeoclimatology, Palaeoecology 153: 17-40.

SakinÇ M., Yaltirak C. \& Aras Perk A. 2007. — İstanbul'un silisleşmiş ağaçları: paleoflora, paleocoğrafya ve paleoiklim. İstanbul'un Jeolojisi III Sempozyumu, İTÜ, İstanbul, 7-9 December 2007: 10-14.

SALVADOR A. 1994. - International Stratigraphic Guide - A Guide to Stratigraphic Classification, Terminology, and Procedure: International Subcommission on Stratigraphic Classification of IUGS International Commission on Stratigraphy. Geological Society of America, Boulder, xix $+214 \mathrm{p}$

SARAÇ G. 1987. - Kuzey Trakya Bölgesinde Edirne-Kırklareli, SarayÇorlu, Uzunköprü-Dereikebir Yörelerinin Memeli Paleofaunası. Master thesis. Ankara Üniversitesi Fen Bilimleri Enstitüsü, Ankara, 109 p. (unpublished).

SAYAR C. 1964. - Ordovician Conulariids from the Bosphorus area, Turkey. Geological Magazine 101: 193-197.

SAYAR C. 1979. - İstanbul-Pendik Kuzeyinde Kayalıdere Grovaklarının Biyostratigrafisi ve Brakiyopodları. (Biostratigraphy and Brachiopodas of Greywackes in Kayalıdere, North of İstanbulPendik). PhD Thesis, İstanbul Teknik Üniversitesi Maden Fakültesi (in Turkish with English abstract, unpublished), 128 p. + xxxvi tables.

SAYAR C. 1984. - Istanbul çevresinden Ordovisiyen Brakiyopodlari (Ordovician Brachiopods from Istanbul, Turkey). Bulletin of the Geological Society of Turkey 27: 99-109.

SAYAR C. 1987. — Istanbul ve çevresi Neojen çökelleri ve Paratetis içindeki konumu. Maden Fakültesi 40 Yll Bülteni, 250-266.

SAYAR C. \& Cocks L. R. M. 2013. - A new Late Ordovician Hirnantia brachiopod Fauna from NW Turkey, its biostratigraphical relationships and palaeogeographical setting. Geological Magazine 150: 479-496.

SAYDAM D. G. 2005. - Beykoz, Şile ve Kurtdoğmuş Yöresindeki Erken-Orta Devoniyen Yaşlı İstiflerin Conodont Faunası, İstanbul, Kuzeybatı Türkiye. (Condont Fauna of Lower-Middle Devonian Sequence in Beykoz, Şile and Kurtdoğmuş Region, NW Turkey). MSc Thesis, Fen Bilimleri Enstitüsü, Ankara Universitesi (in Turkish with English abstract, unpublished).

Sen F., Koral H. \& PeYtcheva I. 2015. - Tectonic significance of intrusions (dyke-sill-stock) cross-cutting deposits of the Rheic Ocean, İstanbul, NW Turkey. 100th Anniversary Symposium of the Geology at Istanbul University, Books of Abstracts, İstanbul.

ŞENGÖR A. M. C. 2011. — İstanbul Boğazı niçin Boğaziçi'nde açılmıştır? Fiziki coğrafya araştırmaları; sistematik ve bölgesel. Türk Coğrafya Kurumu Yayınları 5: 57-102.

ŞENGÖR A. M. C. \& ÖZGÜL N. 2011. — İstanbul șehrinin iklimi ve jeolojisi. İstanbul Ansiklopedisi. NTV Yayznları, İstanbul.

ŞENGÖR A. M. C. \& YILMAZ Y. 1981. - Tethyan evolution of Turkey: a plate tectonic approach. Tectonophysics 75: 181-241.

ŞENGÖR A. M. C., YILMAZ Y. \& KETIN İ. 1980. — Remnants of a prelate Jurassic ocean in northern Turkey: fragments of Permo-Triassic Paleo-Tethys? Geological Society of America Bulletin 91: 599-609.

Sestini N. F. 1988. - Anisian Ammonites from Gebze area (Kocaeli Peninsula, Turkey). Rivista Italiana di Paleontologia e Stratigrafia 94 (1): 35-80.
SÖNMEZ-GÖKÇEN N. 1973. — Étude paléontologique (Ostracodes) et stratigraphique de niveaux du Paléogéne du Sud-Est de la Thrace. Maden Tetkik ve Arama Enstitüsü 47 (1-3): 1-118.

SPRATT T. A. B. 1857. - On the freshwater deposits of Euboea, the coast of Greece and Salonika. Quarterly Journal of the Geological Society 13: 177-184.

Steininger F. F. \& Wessely G. 1999. — From the Tethyan Ocean to the Paratethys Sea: Oligocene to Neogene Stratigraphy, Paleogeography and Paleobiogeography of the circum-Mediterranean region and the Oligocene to Neogene Basin evolution in Austria. Mitteilungen der Österreichischen Geologischen Gesellschaft 92: 95-116.

SUESS E. 1866. - Untersuchungen über den Charakter der österreichischen Tertiärablagerungen. II. Über die Bedeutung der sogenannten „brackischen Stufe“ oder der "Cerithienschichten”. Sitzungsberichte der kaiserlichen Akademie der Wissenschaften, mathematisch-naturwissenschaftliche Klasse C 54 (1): 218-260.

TChinatchef P. A. DE 1864. - Le Bosphore et Constantinople avec Perspectives des Pays Limitrophes. Th. Morgand, Paris, XII + 589 p. +9 pls +2 foldout maps.

TChinATCheF P. A. DE 1866. - Asie Mineure - description physique de cette contrée - première partie: géographie, physique compare. L. Guérin, Paris, xxiii +609 p.

TOULA F. 1896. - Eine Muschelkalkfauna am Golf von Izmit in Kleinasien. Beiträge zur Paläontologie und Geologie Österreich-Ungarns und des Orients 10 (4): 153-191.

ToUla F. 1898. - Eine geologische Reise nach Kleinasien (Bosporus und Südküste des Marmarameeres). Beiträge zur Paläontologie und Geologie Österreich-Ungarns und des Orients 12 (1): 1-27.

TÜrKECAN A. \& YURTSEVER A. 2002. - Geological map of Turkey, Istanbul, 1: 500000 ölçekli Türkiye Jeoloji Haritası Serisi. Maden Tetkik ve Arama Genel Müdürlüğ̈̈, Ankara.

TÜYSÜZ O., AKSAY A. \& YıĞITBAŞ E. 2004. — Batı Karadeniz Litostratigrafi Birimleri. MTA Stratigrafi Komitesi Litostratigrafi Birimleri Serisi 1: 1-92.

Umut M., İmik M., Kurt Z., Ozcan I., Ates M., KarabiYiKoGLU M. \& SARAÇ G. 1984. — Edirne ili Kırklareli ili-Lüleburgaz (Kırklareli ili), Uzunköprü (Edirne ili) civarının jeolojisi. Maden Tetkik ve Arama Enstitüsü, Report no. 7604, 1-42 p. (unpublished).

Umut M., Kurt Z., İMIK M., ÖZCAN İ., SARIKaYa H., SARAÇ G. \& KESKIN İ. 1983. — Tekirdağ İli-Silivri (İstanbul İli)-Pınarhisar (Kırklareli İli) alanının jeolojisi. Maden Tetkik ve Arama Enstitüsü, Ankara. Report no. 7349 (unpublished).

ÜNAL O. 1967. — Trakya jeolojisi ve petrol imkanları. TPAO Report no. 391.

UstaÖmer P. A. 1999. - Pre-Early Ordovician Cadomian arc-type granitoids, the Bolu Massif, west Pontides, northern Turkey: geochemical evidence. International Journal of Earth Sciences 88 (1): 2-12.

Ustä̈mer P. A., Ustä̈mer T., Gerdes A. \& Zulauf G. 2011.Detrital zircon ages from a Lower Ordovician quartzite of the Istanbul exotic terrane (NW Turkey): evidence for Amazonian affinity. International Journal of Earth Sciences 100: 23-41.

VERNEUIL E. DE 1837. - Notice géologique sur les environs de Constantinople. Bulletin de la Société géologique de France, série 1, 8: 268-278.

YAZMAN M. \& ÇOKUĞRAŞ R. 1983. — Adapazarı-Kandıra-DüzceAkçakoca yerleşim merkezleriyle sınırlı alanın jeolojisi ve hidrokarbon olanakları. TPAO Report No 1747.

YILMAZ İ. 1977. - Absolute age and genesis of the Sancaktepe granite (Kocaeli peninsula). Bulletin of the Geological Society of Turkey 20: 17-20 [in Turkish].

Yilmaz-ŞAhin S., AYSAL N., GÜNGÖR Y. \& ÖNGEN S. 2010. - Petrogenesis and shrimp zircon U-Pb dating of some granitoids within the western Pontides, southeastern Balkans, NW Turkey. XIX Congress of Carpathian-Balkan Geological Association, Thessaloniki, Greece, 23-26 September. Geologica Balcanica: 419. 
YilmaZ-ŞAHIN S., AYSAL N. \& GÜNGÖR Y. 2012. — Petrogenesis of Late Cretaceous Adakitic Magmatism in İstanbul Zone (Çavuşbaşı granodiorite, NW Turkey). Turkish Journal of Earth Sciences 21: 1029-1045.

YURTSEVER A. 1982. - Kocaeli Triyası biyostratigrafi projesi, Gebze-Hereke-Tepecik alanında Mesozoyik-Senozoyik kayalarının jeolojisi. MTA Report no. 7195 (unpublished).

YURTTAS-ÖZDEMIR Ü. 1971. — Kocaeli Yarımadası, Tepeköy Triası makrofaunası ve biostratigrafisi. Maden Tetkik ve Arama Dergisi 77: 57-99. YuRTTAS-ÖZDEMİ Ü. 1973. — Über den Schieferton Mit Halobia der Halbinsel Kocaeli. Bulletin of the Mineral Research and Exploration Institute 80: 43-49.

Submitted on 15 January 2016; accepted on 4 May 2016; published on 24 June 2016. 